\title{
LOS RECURSOS EN EL NUEVO CÓDIGO PROCESAL PENAL. DISPOSICIONES GENERALES, RECURSO DE REPOSICIÓN Y APELACIÓN*
}

\author{
Guillermo Piedrabuena Richard
}

Fiscal Nacional

Profesor Titular de Derecho Procesal

Pontificia Universidad Católica de Chile

\section{1) DISPOSICIONES GENERALES}

a) Cuáles son los recursos y su ubicación en el nuevo Código.

El Libro Tercero del nuevo Código Procesal Penal que se refiere a los recursos menciona como tales al recurso de reposición (Título II, Arts. 362 y 363), al recurso de apelación (Título III, Arts. 364 a 371) y al recurso de nulidad (Título IV, Arts. 372 a 387). No se menciona al actual recurso de revisión puesto que esta institución no está configurada como recurso en el nuevo Código sino como un procedimiento especial denominado "Revisión de las sentencias firmes" (Arts. 473 a 480), siguiendo la tendencia doctrinaria que no considera a la revisión como un recurso procesal.

Ahora bien, se consagra además un Título I en el Libro III, relativo a las disposiciones generales aplicables a los recursos (Art. 352 a 361) que es menester analizar previamente.

Desde luego y aunque el Libro III se denomine "Recursos" y no "Recursos Procesales", ello no significa que el sistema de recursos del nuevo Código sea aplicable a aquellas reclamaciones o recursos extraprocesales que no están dirigidos en contra de ninguna resolución judicial. Es así, como diversas normas del nuevo Código se refieren a los reclamos que pueden interponer los intervinientes en contra de los fiscales, algunos de los cuales conoce la autoridad superior del Ministerio Público, esto es el Fiscal Regional, y otros el Juez de Garantía.

Estos otros reclamos no son auténticamente recursos procesales porque no se deducen en contra de una resolución judicial, sino que de una administrativa del fiscal.

\footnotetext{
* Este trabajo corresponde a una exposición efectuada en la Universidad Católica del Norte, Sede Coquimbo, complementada posteriormente con las notas y referencias a los instructivos de la Corte Suprema sobre el recurso de apelación.
} 
Estos reclamos no forman parte de los recursos mencionados en el Libro III, son de una naturaleza diversa y su tramitación no está regulada en la ley, por lo que el fallo de la reclamación debe hacerse con conocimiento y sin ningún otro trámite intermedio, salvo el envío de los antecedentes respectivos.

También hay situaciones en que las decisiones del fiscal deben ser aprobadas por el fiscal regional, como la que se refiere al archivo provisional de una investigación por delito que merece pena aflictiva (Art. 167 inc. $2^{\circ}$ ), o por el juez de garantía, como las que se refieren a la facultad para no iniciar investigación (Art. 168), o las que se refieren al ejercicio del principio de oportunidad (Art. 170). En estos casos, no se trata de una solicitud del fiscal al juez de garantía o al fiscal regional, sino que se trata de una comunicación y el envío de los antecedentes respectivos a aquellos, para la aprobación de la decisión del fiscal.

En consecuencia, las disposiciones generales y particulares del Libro III sólo se refieren a los recursos de reposición, apelación y nulidad y no a aquellas reclamaciones - aprobaciones que el Código establece respecto de las decisiones de los fiscales en situaciones precisas y determinadas.

El recurso de reposición se entabla y se resuelve por el mismo tribunal, unipersonal o colegiado, que ha pronunciado la resolución recurrida.

El recurso de apelación se deduce ante el juez de garantía y se falla por la Corte de Apelaciones respectiva.

El recurso de nulidad se interpone ante el tribunal colegiado del juicio oral, para ante la Corte Suprema o la Corte de Apelaciones respectiva, según sea la causal del recurso.

La Cámara de Diputados había establecido un recurso extraordinario en contra de la sentencia definitiva condenatoria del juicio oral que se apartaba manifiesta y arbitrariamente de la prueba rendida en la audiencia, como paliativo de la improcedencia de la apelación en el juicio oral.

El Senado suprimió este recurso extraordinario por innecesario y en el entendido de que el nuevo recurso de nulidad serviría como paliativo del recurso extraordinario, en una especie de mezcla entre apelación y casación, y que las causales del recurso de nulidad serían interpretadas en forma amplia y no formalista y restrictiva.

En efecto, la Comisión de Legislación del Senado junto con confirmar el criterio de que no debe existir apelación en el juicio oral para no desvirtuar la esencia de este juicio, eliminó el recurso extraordinario haciendo suya la tendencia doctrinaria que estima "que la casación suple sin duda a la apelación" y que se cumple con el requisito 
del Pacto de San José (Art. $8^{2}$ ) posibilitando el derecho de reclamo a través de una "casación abierta no excesivamente formalista, que permite a las partes obtener una revisión de lo ocurrido durante el juicio oral" (Segundo Informe, pág. 344 y 345). Sobre este punto volveremos a su análisis, al tratar el recurso de nulidad en un futuro instructivo.

\section{b) Características del nuevo sistema de recursos.}

En términos generales, el nuevo sistema de recursos es restrictivo y excepcional, careciendo de la amplitud del sistema actual del Código de Procedimiento Penal.

La razón de este cambio dice relación con la concepción acusatoria del nuevo sistema penal, en que se restringe la actuación de los Tribunales Superiores a los recursos de las partes agraviadas y en base a causales y requisitos estrictos. Especialmente limitado se encuentra el recurso de apelación que sólo se concede en contra de determinadas resoluciones dictadas por el juez de garantía, siendo inapelables las resoluciones del tribunal colegiado del juicio oral.

Por vía ilustrativa, es útil citar al procesalista Alex Carocca, que en sus comentarios sobre recursos en el nuevo sistema procesal penal (Nuevo Proceso Penal. Editorial Jurídica Conosur Ltda., p. 288), expresa que en el sistema anterior que califica como inquisitivo "el recurso es concebido como un mecanismo de control de tipo jerárquico de un tribunal superior respecto del inferior, mientras que en el segundo (acusatorio), se le considera como un instrumento a disposición de las partes -siendo inconcebible, por ende, una revisión de oficio- para obtener resoluciones dotadas de la mayor legitimidad posible, vigilando especialmente que en su producción se hayan respetado todas las garantías de orden procesal".

También debe destacarse en la misma dirección, que el nuevo sistema elimina enteramente el trámite de la consulta obligatoria, mediante el cual determinadas sentencias o resoluciones dictadas en procesos por delitos que merezcan pena aflictiva o en otros casos excepcionales, deben ser revisadas por el Tribunal Superior si no son apeladas.

Asimismo, ciertamente influye en el carácter restrictivo de los recursos del nuevo sistema, la necesidad de acelerar el desarrollo del proceso penal y terminar con la infinidad de recursos que dilatan el pronto término del conflicto penal.

Luego de este preámbulo, debemos referirnos a algunas de las disposiciones generales del Título I del Libro III del nuevo Código. 
c) Facultad de recurrir. (Art. 352).

Se reconoce que esta facultad le corresponde al "ministerio público y los demás intervinientes agraviados" por las resoluciones judiciales.

En el proyecto aprobado por la Cámara de Diputados se establecía únicamente que podían recurrir "los intervinientes agraviados" por las resoluciones judiciales y aquellos "a quienes la ley reconociere expresamente este derecho", omitiendo señalar al Ministerio Público o a sus fiscales.

Estimamos que esta omisión no era casual, porque, para algunos intérpretes de la reforma procesal penal, es improcedente que el Ministerio Público pueda recurrir en contra de ninguna resolución judicial. Al respecto, cabe señalar que uno de los juristas extranjeros que más ha influido en la reforma procesal chilena, el Profesor Julio Maier, sostiene que sólo corresponde el derecho a recurrir al imputado y en contra de las sentencias condenatorias, nunca para el acusador, de suerte que las sentencias absolutorias serían irrecurribles. Tesis que es rebatida por otros juristas, como Montero Aroca, el cual sostiene que la posición anterior corresponde al sistema anglosajón y no al sistema continental y que proscribir el recurso acusatorio significaría desconocer los principios de igualdad de las partes y del contradictorio, que hace a la esencia misma del proceso del mundo Eurocontinental, que no admite impugnaciones privilegiadas ("El recurso de apelación penal", César San Martín Castro, Profesor de Derecho Procesal de la Pontificia Universidad Católica del Perú, ponencia en el Congreso de la Reforma Procesal Penal en Pucón, octubre 2000).

Este Fiscal Nacional representó en la Comisión de Legislación del Senado su preocupación por la aparente eliminación del Ministerio Público y de la parte acusadora, de aquellos que podían recurrir en el nuevo proceso penal.

Por lo anterior, en la Comisión de Legislación del Senado se dejó constancia que "el Sr. Fiscal Nacional pidió que se precisara que los fiscales tienen derecho a ocurrir ante los Tribunales Superiores de Justicia y que pueden recurrir aunque el ministerio público no resulte agraviado, en interés de la ley o de la justicia" (pág. 337 del Segundo Informe).

La citada Comisión opinó que "en la medida en que el fiscal es uno de los intervinientes en el procedimiento -como contempla el artículo 12 del proyecto que sugerimos-, queda satisfecha la primera de esas inquietudes, pero convino en mencionarlo expresamente en esta oportunidad" (pág. 337).

De modo que ningún intérprete podrá discutir la calidad o el interés que tiene el Ministerio Público para recurrir, invocando precedentes del sistema anglosajón. Además, es obvio que si el Ministerio Público tiene legitimidad como recurrente, con 
mayor razón la tiene como parte recurrida para defender una resolución judicial de los recursos que se hayan interpuesto en su contra si los estima improcedentes.

El segundo tema es más discutible y es el que se relaciona con el requisito del agravio que se exigiría para todos los intervinientes que recurren. Al respecto, la Comisión consideró textualmente que "el fundamento inherente al recurso es el agravio, de modo que, para no asignar al Ministerio Público un papel de privilegio frente a los demás intervinientes, sólo podrá recurrir cuando es agraviado. Entendió la preocupación del señor Fiscal referida más bien a la dificultad que podría presentarse en algún caso concreto para determinar si ha sufrido agravio, y, al efecto, dejó expresa constancia que considera que el ministerio público es agraviado cuando no fueren acogidas sus peticiones de cualquier manera, sea en la calificación del delito, en la extensión de la pena o en el grado de participación que le haya cabido al imputado, es decir, tanto si la sentencia concede menos como si concede más de lo que el fiscal hubiere pedido".

No obstante, que esta constancia legislativa aparentemente es definitiva, en cuanto a que la necesidad del agravio debe darse también respecto de los fiscales, no es menos cierto que tratándose de un organismo que se rige por los principios de objetividad y legalidad, pueden presentarse situaciones en que el concepto del agravio tendrá que ser interpretado de una manera amplia y no demasiado formalista.

En efecto, no en vano existe una norma actual en el Código de Procedimiento Penal, artículo 511, que permite al fiscal judicial apelar de toda sentencia cuando a su juicio no se haya apreciado correctamente el delito o no haya impuesto al culpable la pena determinada por la ley. Por otra parte, también tenemos el artículo 36 del mismo Código que dispone que el Ministerio Público no podrá desistirse de la querella o acusación intentada, pero podrá pedir, a su tiempo, el sobreseimiento o la absolución del procesado cuando así lo estimare de derecho. Estas conductas se imponen al Ministerio Público por exigirlo así el interés general de la sociedad y de la ley, de acuerdo al Art. 360 inc. $2^{\circ}$ del Código Orgánico de Tribunales que se encuentra vigente.

Por consiguiente, el concepto del agravio no es idéntico tratándose de un interviniente corriente que no tiene la naturaleza y rol que desempeña el fiscal en todo proceso penal. En consecuencia, habrán situaciones limítrofes en que la existencia del agravio respecto del Ministerio Público, tendrá que ser interpretada de manera amplia considerando la naturaleza de sus funciones. 
d) Aumento de los plazos para recurrir en contra de la sentencia de un juicio oral. (Art. 353).

Esta norma establece que "si el juicio oral hubiere sido conocido por un tribunal que se hubiese constituido y funcionado en una localidad situada fuera de su lugar de asiento, los plazos legales establecidos para la interposición de los recursos se aumentarán conforme a la tabla de emplazamiento prevista en el artículo 259 del Código de Procedimiento Civil".

La aplicación de esta norma está limitada al juicio oral y dentro del juicio oral sólo a la situación de un tribunal que se hubiere constituido fuera del lugar de asiento del tribunal oral, posibilidad que está permitida en el nuevo Art. 21 A) del Código Orgánico de Tribunales para facilitar la aplicación oportuna de la justicia penal, lo que determina anualmente la Corte de Apelaciones respectiva.

De modo que, siendo inapelable la sentencia del tribunal oral en lo penal, la norma está referida a la posible ampliación de plazos respecto del recurso de nulidad, único recurso permitido por la ley en contra de dicha sentencia.

Por lo anterior, no es dable aplicar esta ampliación de plazo al recurso de apelación en el procedimiento abreviado (Art. 414), ni a los recursos de nulidad en contra de las sentencias pronunciadas en los procedimientos simplificado y por delitos de acción privada (Arts. 399 y 405).

e) Renuncia y desistimiento de los recursos (Art. 354).

Esta norma se refiere a distintas materias, a saber: a) Renuncia de los recursos: b) Desistimiento de los mismos; c) Facultades del defensor en lo relativo a la renuncia y el desistimiento.

a) Renuncia de los recursos: "Los recursos podrán renunciarse expresamente, una vez notificada la resolución contra la cual procediere".

El sentido de la norma es muy claro ya que indica que las renuncias sólo pueden ser expresas y no tácitas y que sólo pueden renunciarse los recursos "una vez notificada la resolución contra la cual procediera", lo que excluye la eficacia de una renuncia efectuada con anticipación a la notificación de la resolución respectiva. En esta parte, el nuevo Código se aparta del criterio actual que permitía las renuncias anticipadas. 
b) Desistimiento de los recursos: "Quienes hubieren interpuesto un recurso podrán desistirse de él antes de su resolución".

Por consiguiente, la oportunidad para el desistimiento sólo precluye en el momento que el recurso es resuelto $y$, por lo tanto, el desistimiento es posible aunque se haya procedido a la vista del recurso, siempre que éste no haya sido resuelto.

Aunque la norma no lo establece, siempre se ha entendido que un recurso sólo puede ser desistido una vez que se haya interpuesto y concedido por el tribunal correspondiente. Esto diferencia al desistimiento de la renuncia, ya que ésta si puede presentarse una vez notificada la resolución recurrida, antes de que se haya concedido el recurso y aún antes que haya transcurrido el plazo para recurrir.

Más adelante, el inciso segundo del Art. 354 dispone que "en todo caso, los efectos del desistimiento no se extenderán a los demás recurrentes o a los adherentes al recurso".

El desistimiento es individual y por ello no podría afectar a otros recurrentes o adherentes, sin perjuicio de que en ciertos casos las decisiones favorables a uno de los imputados por un mismo delito pudieren aprovechar a los demás imputados (Art. 360 inc. $2^{\circ}$ ), pero ésta es una materia diversa que no está relacionada directamente con el desistimiento.

El último comentario es que, en esta parte, la ley da a entender claramente que acepta la adhesión a los recursos. En el caso del recurso de nulidad, tal posibilidad está reconocida expresamente en el Art. 382 inc. $2 \%$, siempre que se formule la adhesión en la oportunidad que allí se indica y se cumplan los requisitos legales. En el caso del recurso de apelación, no existe norma legal expresa que se refiera a este tema, lo cual no obsta a su procedencia si se sigue el criterio del Art. 354 y el criterio general de la adhesión al recurso, acogido en los Arts. 216 y 217 del C. de Proc. Civil, aplicables también al nuevo procedimiento penal en virtud de lo dispuesto en el Art. 52 del nuevo Código. En todo caso, no está regulada la oportunidad o el procedimiento para la adhesión a la apelación, omisión que podría ser subsanada en una ley adecuatoria o modificatoria futura.

c) Facultades del defensor para renunciar a la interposición de un recurso o desistirse de los recursos interpuestos. (Art. 354 inc. $3^{\circ}$ ).

El nuevo Código exige un mandato expreso del imputado para la renuncia o el desistimiento de los recursos. Ello significa, incuestionablemente, que no es suficiente el poder ordinario conferido a los mandatarios judiciales, sino que se requiere de un mandato especial y expreso para poder renunciar o desistirse de los recursos. Este 
precepto cambia el criterio legal seguido hasta ahora en lo que respecta al desistimiento de los recursos, en que se había estimado que bastaba el mandato ordinario y no se requería de un poder especial, a diferencia de la renuncia en que si se exige un poder especial (Art. $7^{\circ}$ inc. $2^{\circ}$ ). Seguramente, el criterio que inspiró esta modificación es de carácter garantístico y de protección de los derechos del imputado, tal como sucede con numerosas otras normas del nuevo Código.

No obstante lo anterior, la norma sólo se refiere a la renuncia y desistimiento de los recursos del imputado y no a los de los demás intervinientes, por lo que respecto de éstos será necesario un poder especial sólo en caso de la renuncia de los recursos legales y no respecto del desistimiento de los mismos.

\section{f) Efecto de la interposición de recursos (Art. 355).}

Dicha norma establece que "la interposición de un recurso no suspenderá la ejecución de la decisión, salvo que se impugnare una sentencia definitiva condenatoria - que la ley dispusiere expresamente lo contrario".

Este criterio normativo armoniza parcialmente con otras disposiciones del nuevo Código que, por ejemplo, establecen que la regla general en materia de los efectos del recurso de apelación es que este recurso se conceda sólo en el efecto devolutivo, a menos que la ley señalare expresamente lo contrario, sin distinguir si la sentencia es condenatoria o absolutoria (Art. 368). Tampoco concuerda exactamente con lo dispuesto en el Art. 414 que dispone que la sentencia dictada por el juez de garantía en el procedimiento abreviado, será apelable y este recurso deberá concederse en ambos efectos, sin distinguir si la sentencia es absolutoria o condenatoria. En cambio, el Art. 355 es perfectamente compatible con lo dispuesto en el Art. 379 el cual dispone que el recurso de nulidad suspende los efectos de la sentencia condenatoria recurrida y no los efectos de la sentencia absolutoria.

Por vía de interpretación, entendemos que el recurso en contra de una sentencia condenatoria siempre suspende la ejecución de la decisión y la absolutoria no la suspende, a menos que una disposición legal expresa y especial establezca lo contrario.

g) Aplicación supletoria de las normas del Título III del Libro Segundo del nuevo Código, a los recursos (Art. 361).

El Art. 361 establece que los recursos se regirán por las normas de este Libro Tercero y supletoriamente por las del Título III del Libro Segundo, esto es, por las reglas del juicio oral (Arts. 281 a 351). 
La Cámara de Diputados había establecido, en cambio, que eran aplicables en forma supletoria las disposiciones del Título XVIII del Libro Primero del Código de Procedimiento Civil.

Al respecto, la Comisión del Senado estimó que "una remisión a las normas comunes de la apelación civil, podría entrabar el recurso, porque son sistemas incompatibles y porque el Código de Procedimiento Civil está enfocado hacia un procedimiento inquisitivo y escrito". Luego se agregó que "como consecuencia del propósito de desformalizar el conocimiento de los recursos, la Comisión suprimió este artículo e incorporó en el Título I entre las disposiciones generales un artículo con el número 363 que señala que los recursos se regirán por las normas de este Libro, y supletoriamente serán aplicables las reglas del Título III del Libro Segundo de este Código, sobre juicio oral".

No obstante esta constancia legislativa, deben formularse algunas reservas en los siguientes aspectos: a) De toda forma existe una aplicación supletoria del Libro I del Código de Procedimiento Civil al nuevo procedimiento penal, porque así lo dispone expresamente otra norma del nuevo Código, el artículo 52; b) Los conceptos de vista de la causa, suspensión de la misma, agregación extraordinaria y otras materias conexas, están definidos en el Código de Procedimiento Civil, no obstante la presencia de disposiciones especiales en los Arts. 356, 357 y 358; c) Si no se admite la aplicación supletoria del Código de Procedimiento Civil al nuevo procedimiento penal, que por lo demás armoniza con el Código Orgánico de Tribunales vigente, no se pueden entender y aplicar numerosas instituciones que están conceptualizadas en el Código tipo u ordinario.

De allí que entendemos que las referencias al juicio oral se refieren, más bien, a la posible aplicación de las reglas de publicidad, transparencia y de contradicción propias del juicio oral. No existe reserva ninguna en la vista de la causa, la audiencia es pública y las pruebas cuando ellas son procedentes (Art. 359), deben rendirse de la manera dispuesta en el juicio oral.

\section{2) RECURSO DE REPOSICIÓN}

El recurso de reposición está regulado en los artículos 362 y 363 del nuevo Código. El primero de estos preceptos se refiere a la reposición de las resoluciones dictadas fuera de audiencia y el segundo, se refiere a las reposiciones en las audiencias orales, de modo que, es necesario hacer una diferenciación tratándose de las reposiciones de resoluciones dictadas durante las audiencias orales y aquellas dictadas fuera de estas audiencias. 


\section{a) Reposición de las resoluciones dictadas fuera de audiencias (Art, 362).}

El nuevo proceso penal está estructurado en audiencias orales que se verifican, ya sea durante la etapa de la investigación, ya sea durante la preparación del juicio oral y desde luego, está la audiencia misma del juicio oral.

Sin embargo, existen numerosas actuaciones, algunas de ellas que se hacen por escrito, que no se realizan en las audiencias orales y consecuencialmente, hay resoluciones que se dictan fuera de estas audiencias. Por ejemplo, las resoluciones del juez de garantía que aprueban o no aprueban la decisión del fiscal ejerciendo el principio de oportunidad (Art. 170) o sobre su decisión de no iniciar investigación (Art. 168), serían de aquellas que admitirían una reposición del fiscal o de otro interviniente. También podríamos dar como ejemplo a la resolución del juez de garantía que no da tramitación a la querella que le ha presentado por escrito el querellante (Art. 114) y la que rechaza de plano la petición del imputado para revocar la resolución que dispuso su prisión preventiva (Art. 144 inc. $2^{\circ}$ ).

En todo caso, debe tratarse de una resolución dictada por un tribunal y no por un fiscal del Mínisterio Público, ya que los recursos tratados en el Libro Ill del nuevo Código sólo incluyen a aquellos tendientes a impugnar resoluciones judiciales, es decir, provenientes del órgano jurisdiccional.

En cuanto a las resoluciones no jurisdiccionales de los fiscales, el nuevo Código no se refiere a esta materia, no obstante que, de acuerdo a principios generales de derecho, cualquier órgano no jurisdiccional que adopte una decisión debe estar dispuesto a aceptar una reconsideración de la misma, si la encontrare procedente.

Ahora bien, si se trata de una resolución dictada en cualquiera de estas audiencias orales, la reposición está regulada en el Art. 363 que veremos más adelante, por lo que limitaremos nuestro análisis al caso de las reposiciones de las resoluciones dictadas fuera de las audiencias orales.

En relación a la procedencia de la reposición, el Art. 362 inc. $1^{\circ}$ dispone que "de las sentencias interlocutorias, de los autos y de los decretos dictados fuera de audiencias, podrá pedirse reposición al tribunal que los hubiere pronunciado". Más adelante, el mismo precepto agrega que el tribunal se pronunciará de plano, pero también podrá escuchar a los demás intervinientes cuando la complejidad del asunto así lo aconsejare.

Por lo anterior, no es procedente ninguna reposición en contra de una sentencia definitiva dictada sea en el juicio oral, o en el procedimiento abreviado, o en el procedimiento simplificado o en cualquier otro en que el objeto del juicio sea resuelto mediante una sentencia. El concepto de sentencia definitiva está definido en el Art. 158 
inc. $2^{\circ}$, al mencionarse que debe considerarse como tal a la resolución "que pone fin a la instancia, resolviendo la cuestión o asunto que ha sido objeto del juicio".

Enseguida, debe tenerse presente que el nuevo Art. 362 es bastante similar al actual Art. 56 del Código de Procedimiento Penal, tanto en la naturaleza de las resoluciones susceptibles del recurso de reposición, como en cuanto a la tramitación del recurso.

En efecto, el tribunal puede acoger o rechazar una reposición de plano, pero también puede resolver escuchando previamente al resto de los intervinientes del nuevo proceso.

Este tribunal, por regla muy general, será el juez de garantía y no el tribunal del juicio oral porque, aun cuando la norma no distingue, es muy difícil que una resolución se haya pronunciado por el tribunal del juicio oral fuera de la audiencia misma. Es posible que, excepcionalmente, este último tribunal dicte algunas resoluciones a fin de otorgar un plazo adicional para la redacción de la sentencia en el caso del artículo 344 o resuelva con posterioridad a la sentencia, dictar algunas resoluciones complementarias respecto de las medidas cautelares personales, en la situación prevista en el Art. 347.

No cabe duda que cuando se interpone una reposición en contra de una sentencia interlocutoria, se está afectando el principio y efecto del desasimiento del tribunal previsto en el Art. 182 del Código de Procedimiento Civil. Sin embargo, este principio general tiene excepciones en el propio procedimiento civil y desde luego en el procedimiento penal (Art. 56 del Código de Procedimiento Penal y Art. 362 del Código Procesal Penal).

Cabe preguntarse, cuáles serían las sentencias interlocutorias que pueden dictarse por un juez de garantía en el nuevo procedimiento penal, fuera de las audiencias orales. Al respecto, podríamos mencionar a las que se dicten por este tribunal para resolver un incidente de incompetencia o a las relativas al forzamiento de la acusación en que se acoja o se rechace la petición del querellante (Art. 258 inc. final). También puede mencionarse a las resoluciones del juez de garantía que aprueben las decisiones de los fiscales para no investigar o para ejercer el principio de oportunidad (Arts. 168 y 170).

Ahora bien, el Art. 362 inc. 1ำ establece que "el recurso deberá interponerse dentro de tercero día y deberá ser fundado". La norma similar del Art. 56 inc. $2^{\circ}$ disponía que "la reposición sólo puede solicitarse dentro de tercero día y para ser admitida deberá estar siempre fundada", redacción poco precisa y jurídica en cuanto se sitúa el requisito de estar fundada, como un asunto de admisibilidad del recurso. 
Si se trata de una reposición deducida en contra de una resolución dictada fuera de una audiencia oral, el recurso deberá interponerse por escrito y no en forma meramente verbal, porque de lo contrario, el tribunal no podría apreciar si la reposición está o no fundada para darle el curso correspondiente. El asunto cambia cuando las resoluciones son pronunciadas durante las audiencias orales, pues en estos casos, las exposiciones y las alegaciones deben hacerse en forma oral en la misma audiencia.

En su parte final, el Art. 362 inc. $3^{2}$ dispone que "cuando la reposición se interpusiere respecto de una resolución que también fuere susceptible de apelación y no se dedujere a la vez este recurso para el caso de que la reposición fuere denegada, se entenderá que la parte renuncia a la apelación".

Esta norma está copiada del actual Art. 56 inc. $4^{\circ}$ del Código de Procedimiento Penal y es similar a la norma del Art. 188 del Código de Procedimiento Civil. Ella tiene por objeto exigir al recurrente que indique al mismo tiempo que recurre de reposición, que también intenta apelar en contra de la misma resolución, para lo cual debe hacerlo en forma subsidiaria. Si así no lo hace, se tramitará y resolverá su reposición, pero no podrá intentar más adelante un recurso de apelación, aun cuando esté dentro de plazo.

En la normativa actual anterior al nuevo Código se ha planteado, respecto del procedimiento penal, si es posible apelar directamente de la resolución recurrida cuando el recurso de apelación es procedente, sin tener que hacerlo en forma subsidiaria de la reposición.

Al respecto, las opiniones están divididas. El Profesor Cristián Maturana, estima que es posible sostener que la apelación procedería sólo en forma subsidiaria de la reposición y para el evento de no ser ella acogida, opinión que no compartimos, porque estimamos que si se deduce reposición, la apelación debe ser subsidiaria, pero ello no quiere decir que no se pueda apelar directamente de la resolución que es apelable (Ver "El recurso de apelación y la consulta", Guillermo Piedrabuena Richard, pág 65, Editorial Jurídica de Chile, 1999).

Por último, el inciso final del Art. 362 dispone que "la reposición no tendrá efecto suspensivo, salvo cuando contra la misma resolución procediere también la apelación en este efecto", precepto que es idéntico al actual art. 56 inciso final del Código de Procedimiento Penal.

Esto significa que la interposición de una reposición no suspende el cumplimiento o la ejecución de la resolución recurrida, salvo que ésta sea susceptible de apelación y el recurso debiere concederse en ambos efectos, esto es, en los efectos devolutivo y suspensivo. 
Este tema está relacionado con las resoluciones que son susceptibles de apelación y con los efectos de como es concedido el recurso, materias a las cuales nos referiremos en un próximo instructivo:

Por ahora, mencionemos que son apelables, según el Art. 370 del nuevo Código, las resoluciones dictadas por el juez de garantía en los siguientes casos: "a) Cuando pusieren término al procedimiento, hicieren imposible su prosecución o la suspendieren por más de treinta días, y b) Cuando la ley lo señalare expresamente".

De otra parte, por regla general las apelaciones se concederán en el sólo efecto devolutivo, a menos que la ley señalare expresamente lo contrario (Art. 368).

En consecuencia, no tendrá efecto suspensivo la reposición si la resolución no es apelable en ambos efectos $\mathrm{y} / \mathrm{o}$ si no ha sido pronunciada por un juez que no sea el juez de garantía, lo que excluye el efecto suspensivo de todas aquellas resoluciones dictadas por el tribunal del juicio oral porque ellas no admiten apelación.

\section{b) Reposición de las resoluciones dictadas en las audiencias orales.}

El artículo 363 establece que "la reposición de las resoluciones pronunciadas durante audiencias orales, deberá promoverse tan pronto se dictaren y sólo serán admisibles cuando no hubieren sido precedidas de debate. La tramitación se efectuará verbalmente, de inmediato, y de la misma manera se pronunciará el fallo".

Como se explicó anteriormente, en el nuevo proceso penal hay numerosas materias que deben tratarse en las audiencias que se celebren durante la investigación o en la preparación del juicio oral o en el juicio oral mismo, sin perjuicio de las audiencias orales en los procedimientos penales especiales del Libro IV del Código Procesal Penal.

Si durante dichas audiencias, el juez de garantía o el tribunal del juicio oral, se dictan resoluciones, la reposición deberá promoverse tan pronto se dictaren, es decir, sin dilación y de inmediato. En consecuencia, no rige en la especie el plazo de tres días para presentar la reposición a que se refiere el Art. 362 inc. 1ㅇ․

Por la naturaleza de la audiencia oral, la reposición tendrá que promoverse verbal u oralmente y no por escrito, dejándose constancia en el acta respectiva de la audiencia oral.

A su vez, "la tramitación se efectuará verbalmente, de inmediato, y de la misma manera se pronunciará el fallo", todo lo cual confirma que la reposición debe plantearse verbalmente al igual que el resto de la tramitación. 
En cuanto a la admisibilidad de la reposición, el artículo 363 sólo se refiere a que son admisibles las reposiciones "cuando no hubieren sido precedidas de debate", lo que excluye a las reposiciones en caso de que la materia haya sido precedida de debate. Esta norma evidentemente restrictiva tendrá que interpretarse y ser aplicada, según las circunstancias de cada caso. Aparentemente, ha habido debate cuando todos los intervinientes han tenido oportunidad de participar, antes de que el tribunal resuelva la materia. En cambio, si el tribunal se ha pronunciado sin abrir debate, esto es, sin escuchar a los intervinientes, la reposición sería procedente, en especial la que promueva el interviniente que no ha sido escuchado ni ha tenido la oportunidad de participar en el debate.

Sin embargo, hay materias que no están definidas en el artículo 363 ya mencionado, como por ejemplo las siguientes:

a) Resoluciones que son susceptibles de reposición. ¿Son las sentencias interlocutorias, autos y decretos o también se puede pedir repósición de una sentencia definitiva?

Estimamos categóricamente que respecto de una sentencia definitiva no se puede recurrir de reposición, siguiendo los principios generales. De la misma manera, opinamos que los autos y decretos son susceptibles de reposición, conforme a las reglas generales (Arts. 181 y 182 del Código de Procedimiento.Civil).

El asunto es más discutible tratándose de las sentencias interlocutorias, ya que al no existir mención expresa de ellas en el nuevo Art. 363, podría sostenerse que no son susceptibles de reposición, conforme al criterio general de los Arts. 181 y 182 del Código de Procedimiento Civil. No obstante esto y teniendo presente que seguramente existió una omisión del legislador, nos inclinamos a estimar que también puede recurrirse de reposición en contra de las sentencias interlocutorias dictadas durante las audiencias orales, porque no se divisa ninguna razón para no aplicar por analogía lo dispuesto en el Art. 362 inc. $1^{\circ}$ a las resoluciones dictadas en las audiencias orales.

b) Tramitación de la reposición. Si bien el Art. 363 no regula la forma de tramitación, excepto la mención de que tiene que ser verbal, también estimamos que puede aplicarse por analogía la tramitación dispuesta en el Art. 362 inc. $2^{\circ}$ respecto de las reposiciones en contra de resoluciones dictadas fuera de las audiencias orales.

Por consiguiente, se estima que frente a una reposición verbal de uno de los intervinientes, el tribunal podrá resolverla de plano o escuchando al resto de los intervinientes si la complejidad del asunto lo aconsejare.

c) ¿Necesita la reposición ser fundada? Aunque tampoco esta materia está regulada en el Art. 363, forzosa es la conclusión de que ningún tribunal puede tramitar 
una reposición que no se encuentre fundada en los hechos y en el derecho, aunque ésta deba efectuarse en forma verbal. Es decir, no sería suficiente simplemente pedir reposición, sino que además, habría que expresarle al tribunal de la audiencia oral, cuáles serían los fundamentos de la petición.

Finalmente, todas las alternativas que rodean el recurso de reposición promovido en la audiencia oral, incluyendo la resolución verbal del tribunal que debe pronunciar se inmediato, deberán consignarse en las actas respectivas y registrarse debidamente en los registros de las actuaciones judiciales.

d) Lo dispuesto en los incisos $3^{\circ}$ y $4^{\circ}$ del artículo 362 también sería aplicable a la reposición de las resoluciones pronunciadas en las audiencias orales.

No obstante, que el artículo 363 pertinente no menciona la posible aplicación de los incisos $3^{\circ}$ y $4^{\circ}$ del Art. 362 a la reposición de las resoluciones dictadas en las audiencias orales, no es menos cierto que la omisión del legislador debe ser suplida llenándose el vacío legal correspondiente.

En efecto, si es lógico que la reposición no tenga efecto suspensivo por regla general respecto de las resoluciones dictadas fuera de audiencia, con mayor razón tampoco puede suspender los efectos de las resoluciones dictadas en las audiencias orales, porque la resolución del recurso debe hacerse de inmediato, en forma verbal, en la misma audiencia.

La misma razón existe respecto de la estricta necesidad de apelar en forma subsidiaria a la reposición, si se desea conservar el derecho al recurso de apelación, todo esto en el evento de que este recurso sea procedente, porque debemos recordar que todas las resoluciones pronunciadas en el juicio oral por el tribunal colegiado oral en lo penal, no son apelables.

\section{3) EL RECURSO DE APELACIÓN}

\section{a) Resoluciones apelables.}

El artículo 370 que se refiere a la materia dispone que "las resoluciones dictadas por el juez de garantía" serán apelables en los siguientes casos:

a) Cuando pusieren término al procedimiento, hicieren imposible su prosecución o la suspendieren por más de treinta días, y

b) Cuando la ley lo señalare expresamente. 
Por su parte, el artículo 364 del Código dispone que "serán inapelables las resoluciones dictadas por un tribunal de juicio oral en lo penal".

En cuanto a esta última disposición, cabe advertir que la inapelabilidad se establece no sólo para las sentencias que se pronuncien en el juicio oral, sino que también, respecto de todas las resoluciones pronunciadas por el tribunal del juicio oral en lo penal, cualquiera que sea su naturaleza.

Aún más, esta prohibición de apelar rige también en los procedimientos en que son aplicables supletoriamente las normas del juicio oral, como por ejemplo, el procedimiento simplificado (Arts. 389 y 399) y el procedimiento por delito de acción privada (Art. 405), sin perjuicio de que estas normas especiales sólo permiten el recurso de nulidad en contra de la sentencia definitiva.

En cuanto al debate acerca de la conveniencia y hasta posible inconstitucionalidad de las normas que establecen la única instancia en materia penal, ya nos referimos brevemente al tema en las disposiciones generales y mencionamos que para suplir la falta de apelación, se debía interpretar el recurso de nulidad de una manera amplia y no formalista.

Salvo que los tribunales acojan la tesis de la inconstitucionalidad de la única instancia en lo que respecta a las resoluciones y sentencias del tribunal oral en lo penal, hay que regirse íntegramente por el nuevo Código Procesal Penal y a las normas restrictivas de la apelación ya mencionadas. Por ello, en caso de ser necesario un recurso en contra de la sentencia definitiva del juicio oral, habrá que proceder únicamente en base al recurso de nulidad que se establece en el Título IV del Libro III del Código.

En seguida, debe subrayarse que las únicas resoluciones en que se permite la apelación, deben haber sido dictadas por el juez de garantía.

Antes de entrar al análisis más detallado del Art. 370, hay que insistir en la característica del nuevo sistema de recursos en que la apelación es excepcional y es procedente sólo en los casos expresamente previstos por la ley.

En el actual sistema procesal penal se establece una causal genérica del recurso de apelación, que permite este recurso contra toda resolución que causa un gravamen irreparable, fórmula legal que ha dado origen a diversos problemas de interpretación y a una jurisprudencia dividida (ver "El Recurso de apelación y la consulta", Guillermo Piedrabuena Richard, Edit. Jurídica de Chile, 1999, págs. 60 a 67). Esta causal genérica desaparece en el nuevo sistema, lo que evidentemente restringe el recurso a casos excepcionales y la razón doctrinaria se encuentra explicada por el Profesor Carocca, citado en el instructivo № 17. 
Finalmente, el nuevo sistema no vincula el tema de la apelación a la naturaleza de la resolución apelada, a saber, si es sentencia interlocutoria o un auto o decreto, como sí lo hace el actual Art. 54 bis del Código de Procedimiento Penal. En el nuevo Código, las resoluciones son apelables en los casos excepcionales que se establecen en el Art. 370, independientemente de su naturaleza jurídica.

Veamos a continuación las causales excepcionales que permiten apelar de una resolución dictada por un juez de garantía.

a) Cuando pusieren término al procedimiento, hicieren imposible su prosecución o la suspendieren por más de treinta días.

Se trata de resoluciones judiciales emanadas del juez de garantía y no decisiones de los fiscales o de la autoridad superior del Ministerio Público que no constituyen resoluciones de carácter jurisdiccional y que son más bien de carácter administrativo. Por ejemplo, la resolución del Ministerio Público que se relaciona con el archivo provisional (Art. 167).

Por ello, en ningún caso, puede concederse un recurso de apelación en contra de una decisión de un fiscal cualquiera que sea su cargo en el Ministerio Público.

Ahora bien, nos referiremos a distintos casos del nuevo Código que pueden estimarse que corresponden a las resoluciones judiciales mencionadas en la letra a) del Art. 370 , sin que esta enunciación sea taxativa.

\section{a.1 Resoluciones que ponen término al procedimiento.}

Entre éstas podemos mencionar la resolución que sobresee definitivamente en la causa, ya que pone término al procedimiento, aun cuando en este caso, además la ley expresamente permite el recurso de apelación (Art. 253).

También podemos mencionar aquellas resoluciones que pronuncia el juez para aprobar la facultad de no iniciar investigación en los casos previstos en el artículo 168 , esto es, cuando los hechos relatados en la denuncia no fueren constitutivos de delito o cuando los antecedentes y datos suministrados permitieren establecer que se encuentra extinguida la responsabilidad penal del imputado. Entendemos que, en estos casos, cuando el juez aprueba la decisión del fiscal, dicta una resolución que si bien no constituye un sobreseimiento definitivo, produce sin duda los efectos de poner término al procedimiento (Art. 170). Esta resolución no es apelable por el fiscal por falta de agravio, pero sí lo es por la víctima, sea o no querellante.

En efecto, puede que la víctima no haya alcanzado a presentar su querella, pero estimamos que puede hacer valer sus derechos a través del recurso de apelación en 
contra de la resolución aprobatoria del juez y si ya hubiere presentado su querella, con mayor razón podría hacerlo como interviniente querellante en el proceso penal.

En cuanto a la resolución del juez que deja sin efecto la decisión del fiscal cuando ejerce el principio de oportunidad, no es apelable, porque no pone término al procedimiento ni lo suspende. Por el contrario, la resolución del juez obliga al fiscal a continuar con el procedimiento penal y la investigación (Art. 170 inc. $4^{\circ}$ ).

Si el juez no adopta la resolución de dejar sin efecto la decisión del fiscal, se ha entendido que no dicta ninguna resolución aprobatoria y se limita a notificar a los intervinientes de la decisión del fiscal para que hagan uso del recurso de reclamación ante las autoridades superiores del Ministerio Público y por lo tanto, no hay ninguna resolución judicial en contra de la cual pueda apelarse. Esa fue la opinión expresada por el Profesor Tavolari en un reciente Seminario efectuado en la Fiscalía Nacional sobre el principio de oportunidad, no obstante que en la discusión de la Comisión de Legislación del Senado (1² Informe, pág. 149 y 150) hubo opiniones aisladas de alguno de los asistentes que podría ser procedente una apelación, aunque no se profundizó mayormente sobre punto.

Habría un caso especial que está regulado en el Art. 170 inc. $5^{\circ}$ que se pone en la situación de un reclamo del interviniente en el plazo de diez días siguientes a la comunicación de la decisión del fiscal. Si el juez rechaza la reclamación, dictando la resolución respectiva, habría apelación porque la decisión del juez importaría la extinción de la acción penal y ello pone término al procedimiento.

Salvo en este último caso, compartimos la opinión en el sentido de que el Juez sólo dicta resolución en el caso de que deje sin efecto la decisión del Fiscal para ejercer el principio de oportunidad (Art. 170) y que si ello no ocurre, el juez no dictaría una resolución aprobatoria y esperaría el posible reclamo ante la autoridad superior del Ministerio Público De acuerdo a los criterios antes expuestos, la decisión del Fiscal Regional como autoridad superior del Ministerio Público no es susceptible de apelación, por no constituir una resolución judicial o jurisdiccional.

Como se advierte del análisis anterior, la normativa del Art. 170 amerita una revisión legislativa para resolver las numerosas dudas que se presentan.

Por otra parte, hay casos en que el juez puede sobreseer definitivamente en la audiencia de preparación del juicio oral cuando acoge las excepciones de previo y especial pronunciamiento sobre cosa juzgada o sobre extinción de la responsabilidad penal. En estos casos, procede la apelación no sólo porque las resoluciones ponen término al procedimiento, sino que también, porque existe texto expreso de ley que permite la apelación (Art. 253). 


\section{a.2 Resoluciones del juez de garantía que hacen imposible la prosecución del} procedimiento.

Hay varios casos en que el juez de garantía dicta un sobreseimiento temporal en la causa, pero en estos casos, además existe un texto expreso de ley que hace procedente el recurso de apelación.

En efecto, el artículo 253 permite la impugnación por la vía del recurso de apelación ante la Corte de Apelaciones respectiva, del sobreseimiento dictado por el juez de garantía una vez que la investigación concluye.

Si bien el nuevo Código, a diferencia del anterior, no especifica cuales son los efectos del sobreseimiento temporal y únicamente regula los efectos del sobreseimiento definitivo (Art. 251), por la naturaleza de las causales del sobreseimiento temporal, fluye claramente que el procedimiento no puede continuar y se suspende mientras no cesa la causa que provoca este sobreseimiento. La existencia de una cuestión civil previa, la situación de un imputado que no comparece y es declarado rebelde y la del que cayere en enajenación mental después de cometido el delito (Art. 252 letras a), b) y c), no permiten la prosecución del procedimiento.

Por otra parte, el artículo 254 permite solicitar la reapertura del procedimiento "al cesar la causa que hubiere motivado el sobreseimiento temporal", lo que evidencia claramente que el sobreseimiento temporal suspende por tiempo indefinido la prosecución del procedimiento, pero que no es definitivo, al no poner término al procedimiento.

Diversas normas del Código permiten también al juez de garantía decretar el sobreseimiento temporal en otras etapas del proceso y no sólo al cierre de la investigación. Así por ejemplo, tratándose de la cautela de garantías, el Art. 10 inc. $2^{\circ}$ permite al juez de garantía en cualquier etapa del procedimiento, decretar el sobreseimiento temporal del mismo. En este caso, la causal del sobreseimiento no es ninguna de las referidas en el Art. 252, no obstante lo cual, la ley posibilita un sobreseimiento temporal por infracción de las garantías judiciales del imputado y por consiguiente, habrá que interpretar que la resolución es apelable por el fiscal o por el querellante por aplicación de los arts. 253 y 370 letra a).

También, durante el desarrollo de la audiencia de preparación del juicio oral, este mismo juez puede resolver de inmediato las excepciones de incompetencia, litis pendencia y falta de autorización para proceder criminalmente, en cuyo caso, la ley expresamente permite la apelación (Art. 271 inc. $2^{2}$ ). En estos casos, aun cuando no se establece un sobreseimiento temporal, puede sostenerse con fundamento que estamos en presencia de una resolución que tiene este carácter y que, en todo caso, es apelable por mandato de la ley. 
a.3. Resoluciones del juez de garantía que suspenden el procedimiento por más de treinta días.

Hasta ahora no hemos encontrado ninguna resolución de esta característica en el nuevo procedimiento penal. En nuestro sistema, los sobreseimientos temporales no son por plazos definidos o limitados, sino que se mantienen mientras no cesa la causal que motiva este sobreseimiento.

En la historia de la ley encontramos que esta causal de apelación no fue considerada en el proyecto aprobado por la Cámara de Diputados. Es en el segundo trámite constitucional y en el segundo Informe de la Comisión de Legislación del Senado, donde aparece una explicación de este caso.

Al respecto, se dejó constancia que "estimó conveniente la Comisión acotar que no cualquier suspensión del procedimiento da derecho a apelar, sino solamente aquellas que suspendan la prosecución el procedimiento, pero siempre que lo dispongan por más de treinta días. La razón de esto es que el procedimiento admite la posibilidad de suspensión por muy variadas razones y de distinta entidad, de forma tal, que si cualquier suspensión que se decretara habilitara para recurrir de apelación ante la Corte de Apelaciones, se podría ver seriamente entrabada la normal prosecución del caso".

No obstante esta constancia, no existiría procesalmente ninguna resolución del juez de garantía que suspendiera el procedimiento por un plazo fijo superior a treinta días y no se divisa qué facultad tendría para hacerlo con esta limitación.

En el caso de una resolución del juez de garantía que protegiendo las garantías del imputado (Art. 10), sobresee temporalmente en la causa, es apelable según lo ya expuesto, independientemente de la duración de este sobreseimiento.

También los sobreseimientos temporales contemplados en el Art. 252 son por tiempo indefinidos y no pueden ser decretados por más o menos treinta días de duración.

b) Las resoluciones dictadas por el juez de garantía serán apelables en los casos que la ley lo señalare expresamente.

Por vía de ejemplo y sin que la enumeración siguiente sea taxativa, mencionaremos los siguientes casos:

b.1. Resolución que acoge las excepciones de previo y especial pronunciamiento de incompetencia del juez de garantía, de litis pendencia y de falta de autorización para proceder criminalmente, que se pronuncia durante el desarrollo de la audiencia de preparación del juicio oral (Art. 271 inc. $2^{\circ}$ ). 
b.2. Auto de apertura del juicio oral dictado al término de la audiencia de preparación del juicio oral, cuando excluyere pruebas ofrecidas por el Ministerio Público y siempre que el recurso de apelación lo interponga este organismo (Art. 277 inc. final). Esta norma se remite al Art. 276 inc. $3^{2}$ el cual permite excluir pruebas cuando provinieren de actuaciones o diligencias que hubieren sido declaradas nulas y aquellas que hubieren sido obtenidas con inobservancia de garantías fundamentales.

Este recurso de apelación del Ministerio Público es ciertamente privilegiado porque no se concede respecto de la resolución que excluye pruebas ofrecidas por otros intervinientes o cuando intenta el recurso un interviniente agraviado como el querellante, respecto de la exclusión de pruebas del Ministerio Público.

b.3. Apelación de la resolución que declare inadmisible la querella (Art. 115 inc. $\left.1^{\circ}\right)$. Es obvio que el recurso lo intentará el querellante que es la parte agraviada con la resolución. El fiscal no puede intervenir ante el juez de garantía para apelar de esta resolución, ya que no se divisa cuál puede ser el agravio del Ministerio Público en este caso.

En cambio la resolución que admitiere a tramitación la querella será inapelable (Art. 115 inc. $2^{\circ}$ ).

b.4. Resolución que declare el abandono de la querella, siempre que sea pronunciada por el juez de garantía.

Si bien el artículo 120 del Código de Procedimiento Penal considera, entre otras, la situación del abandono de la querella cuando el querellante no concurriere injustificadamente a la audiencia del juicio oral o se ausentare de ella sin autorización del tribunal (Art. 120 letra c), estimamos que la resolución es inapelable en este caso, porque todas las resoluciones dictadas por un tribunal del juicio oral en lo penal son inapelables (Art. 364) y porque está en juego el principio de la inmediación y concentración del procedimiento del juicio oral. Es decir, no son conciliables las disposiciones de los Arts. 364 y 120 inc. final y esta contradicción debería ser resuelta en una futura reforma al Código recién promulgado.

b.5. Resolución que se pronuncia acerca de la suspensión condicional del procedimiento, siempre que el recurso de apelación lo interponga el imputado o el ministerio público o el querellante (Art. 237 inc. 4).

Aparentemente, la víctima estaría excluida de los posibles apelantes, no obstante el derecho que le confiere el Art. 109 letra f) del Código, porque el Art. 237 inc. $4^{2}$ sería especial y porque permitiría la apelación sólo por el imputado, el Ministerio Público o el querellante. Sin embargo, a la víctima le corresponde el derecho a la 
impugnación, porque de acuerdo a las reglas generales, puede ser un interviniente agraviado con la resolución (Art. 352).

b.6. Resolución que procede a la revocación de la suspensión condicional, a petición del fiscal o de la víctima, cuando el imputado incumpliere, sin justificación. grave o reiteradamente las condiciones impuestas, o fuere objeto de una nueva formalización de la investigación por hechos distintos. En este caso, la resolución que revoca la suspensión condicional es apelable por el imputado. (Art. 239).

Si la resolución no revoca la suspensión condicional solicitada por el fiscal o la víctima, entendemos que es apelable por éstos en virtud de lo dispuesto en los Arts. 237 inc. $5^{\circ}$ y 239 inc. final.

b.7. Resolución que ordenare, mantuviere, negare lugar o revocare la prisión preventiva cuando hubiere sido dictada en una audiencia (Art. 149).

b.8. Resolución que negare o diere lugar a una medida cautelar real (Art. 158).

b.9. Resolución que ordenare, mantuviere, negare lugar o revocare una medida cautelar personal (Art. 155 inc. final en relación al Art. 149).

b.10. Sentencia que se pronuncia por el juez de garantía en el procedimiento abreviado (Art. 414).

b.11. Resolución que se pronuncia sobre la querella de capítulos que es apelable ante la Corte Suprema (Art. 427).

b.12. Sentencia que se pronuncia sobre la extradición pasiva, sea favorable o desfavorable, en contra de la cual procede el recurso de apelación y el de nulidad ante la Corte Suprema.

b) Resoluciones respecto de las cuales la ley expresamente prohíbe el recurso de apelación.

Diversas disposiciones legales establecen expresamente casos de resoluciones que son inapelables. En estas situaciones, la apelación está prohibida aunque pueda estimarse que la resolución pone término al procedimiento o suspenda su prosecución.

Mencionaremos sólo algunas resoluciones que son inapelables por mandato de la ley:

a) Resolución dictada sobre auto de apertura del juicio oral, a menos que excluya pruebas ofrecidas por el Ministerio Público y el recurso lo interpusiere este organismo (Art. 277 inc. $2^{2}$ ). 
b) Resolución dictada durante la audiencia de preparación del juicio oral mediante la cual, el juez decide dejar la resolución de las excepciones previas de cosa juzgada y de extinción de la responsabilidad penal, para la audiencia del juicio oral (Art. 271 inc. $3^{\circ}$ ).

c) Resolución que niega lugar a la solicitud del querellante para asumir el papel de acusador en el juicio oral, en el caso de que el fiscal solicite el sobreseimiento o manifieste que no tiene antecedentes para perseverar en el procedimiento, sin perjuicio del recurso de apelación en contra de la resolución que pusiere término al procedimiento (Art. 258 inc. final). inc. $\left.2^{\circ}\right)$.

d) Resolución que declara admisible una querella y ordena tramitarla (Art. 115

e) Resolución que ordenare, mantuviere, negare lugar o revocare la prisión preventiva cuando no hubiere sido dictada en una audiencia (Art, 149).

f) Todas las resoluciones dictadas por el tribunal del juicio oral en lo penal (Art. 364), independientemente si ponen término al procedimiento o hacen imposible su prosecución.

c) Tribunal ante el que se entabla el recurso de apelación.

El artículo 365 dispone que "el recurso de apelación deberá entablarse ante el mismo juez que hubiere dictado la resolución y éste lo concederá o lo denegará".

De modo que si las resoluciones apelables sólo pueden haber sido dictadas por el juez de garantía, el recurso debe entablarse necesariamente ante este tribunal para que lo conceda o lo deniegue y en el primer caso, además, señale en qué efectos concede el recurso.

En esta materia no hay ningún cambio respecto del sistema procesal penal actual que ordena presentar el recurso de apelación ante el mismo tribunal que hubiere dictado la resolución apelada.

d) Tribunal que conocerá del recurso de apelación que se concede.

Los artículos 369 y 371 se refieren al tribunal de alzada que conocerá del recurso de apelación y también del recurso de hecho correspondiente, sin indicar cuál es este tribunal de alzada.

Será necesario entender que este tribunal competente de segunda instancia, es la Corte de Apelaciones respectiva, estimando que para estos efectos los juzgados de 
garantía son análogos a los juzgados de letras de la jurisdicción, con competencia en lo penal.

Si bien el artículo 63 № 1 del Código Orgánico de Tribunales no ha sido modificado por la ley 19.665 que reformó este Código, no es menos cierto que las Cortes de Apelaciones son los tribunales que por naturaleza tienen que conocer de la segunda instancia en las causas civiles y criminales, salvo disposición legal expresa en contrario. (Una ley que modifica el Código Orgánico de Tribunales y que está próxima a publicarse, modifica expresamente el Art. 63 del Código Orgánico de Tribunales para establecer que será la Corte de Apelaciones respectiva la que conozca de las apelaciones que sean procedentes en contra de las resoluciones dictadas por el juez de garantía).

Por otra parte, los tribunales orales en lo penal son tribunales de única instancia y jamás conocen en segunda instancia de las causas que han conocido los juzgados de garantía del nuevo proceso penal.

Por último, habrá que llegar a esta conclusión considerando que los artículos 356, 357 y 358 que se refieren a la vista de la causa de los recursos, suponen la existencia de un tribunal colegiado que conoce de ellos, no siendo un tribunal de apelación la Corte Suprema, por regla muy general.

\section{e) Plazo para interponer el recurso de apelación.}

El artículo 366 establece que "el recurso de apelación deberá entablarse dentro de los cinco días siguientes a la notificación de la resolución impugnada".

Este plazo es fatal, legal y no admite prórrogas. El aumento de plazos que contempla el Art. 353 se refiere únicamente a los recursos que se interponen en contra de un tribunal que conoció de un juicio oral y que se constituyó y funcionó en una localidad situada fuera del lugar de su asiento, hipótesis que es inaplicable a los recursos de apelación deducidos en contra de los jueces de garantía. A su vez, las sentencias pronunciadas en el juicio oral son inapelables.

Se hace presente que el sistema de la apelación fundada y con peticiones concretas que se establece claramente y por primera vez en el proceso penal (Art. 367), no lleva consigo un aumento de los plazos de la apelación como sucede tratándose de la apelación de las sentencias definitivas en el proceso civil.

\footnotetext{
${ }^{1}$ La ley 19.708 publicada en el D.O. de 05.01 .00 modificó expresamente el Art. 63 del Código Orgánico de Tribunales al establecer en el $N^{2} 3$ letra b) la competencia de las Cortes de Apelaciones para conocer en segunda instancia de los recursos de apelación interpuestos en contra de resoluciones dictadas por el juez de garantía.
} 
Los plazos son corridos puesto que no se suspenden por la interposición de los días feriados (Art. 14 inc. $1^{\circ}$ ), no obstante que si el plazo vence en un día feriado, "se considerará ampliado hasta las veinticuatro horas del día siguiente que no fuere feriado" (Art. 14 inc. $2^{\circ}$ ).

Si bien el plazo para apelar no es prorrogable, el apelante puede solicitar un nuevo plazo cuando "por un hecho que no le fuere imputable, por defecto en la notificación, por fuerza mayor o por caso fortuito, se hubiere visto impedido de ejercer un derecho o desarrollar una actividad dentro del plazo establecido por la ley" (Art. 17), debiendo el mismo tribunal resolver esta petición siempre que la solicitud se haya formulado dentro de los cinco días siguientes a aquel en que hubiere cesado el impedimento".

\section{f) Forma de interposición del recurso de apelación.}

El artículo 367 establece que "deberá ser interpuesto por escrito, con indicación de sus fundamentos y de las peticiones concretas que se les formularen".

Llama la atención que el sistema de la apelación procesal civil fundada y con peticiones concretas que estableció la ley 18.705 al reformar el Art. 189 del Código de Procedimiento Civil, haciendo más formalista la interposición de este recurso, haya tenido una influencia en el nuevo proceso penal que es desformalizado y que se caracteriza por la primacía de la oralidad por sobre la escritura.

Esta norma había sido aprobada en la Cámara en la misma forma y en el Senado, su Comisión de Legislación también la aprobó, porque la estimó acertada ya que "evita la presentación de recursos sin fundamentos y facilita su resolución en segunda instancia".

Si a lo anterior se agrega que "concedido el recurso, el juez remitirá al tribunal de alzada copia fiel de la resolución y de todos los antecedentes que fueren pertinentes para un acabado pronunciamiento sobre el recurso", tendremos que concluir que el nuevo sistema de interposición del recurso de apelación, es formalista y solemne, tal como sucederá con el de nulidad.

Sin embargo, llama la atención de que no se hayan considerado normas especiales para los imputados privados de libertad que deben apelar de alguna resolución agraviante, en especial de la relativa a su prisión preventiva. En el actual Código de Procedimiento Penal, artículo 366, el procesado puede apelar en el acto de la notificación de la resolución que deniega la libertad provisional o el monto de su caución, dejándose constancia por el ministro de fe que practique la notificación, si se conforma o apela de la resolución apelada. 
El nuevo sistema procesal penal no considera esta última situación y ello obliga también al imputado privado de libertad a deducir el recurso de apelación por escrito, con fundamentos y con peticiones concretas. Si bien el imputado privado de libertad es notificado en la forma especial prevenida en el artículo 29, es decir, en forma personal en el establecimiento o recinto en que se encontrare, no está en condiciones de apelar en el acto de la resolución agraviante en materia de prisión preventiva, porque deberá deducir el recurso por escrito, en forma fundada y con peticiones concretas y presentarlo ante el Tribunal competente.

La misma problemática se presenta al considerarse que la materia relativa a la prisión preventiva se resuelve generalmente dentro de la audiencia y el imputado y su defensor tienen derecho a hacer alegaciones orales para defender sus derechos. Lamentablemente, en nuestro concepto el Art. 367 es muy claro, en cuanto a exigir que el recurso se presente por escrito, con fundamentación y peticiones concretas, de modo que no podría apelarse en forma verbal en la misma audiencia. Quizás sería conveniente en uná futura reformá, permitirle al imputado privado de libertad deducir apelación en forma verbal, cuando la prisión preventiva o su modificación o revocación es resuelta en una audiencia por el juez.

Esto significa que este imputado debe tener defensor letrado que lo asista en la interposición del recurso, por el tecnicismo legal exigido en el Art. 367, de allí la importancia de la efectiva vigencia de la defensoría penal pública (Ver instructivo № 20).

La consecuencia de la omisión de los requisitos del escrito de apelación no está explicitada en el nuevo Código e interpretando por analogía y en forma supletoria lo dispuesto en el Art. 201 del Código de Procedimiento Civil, tendríamos que concluir que la infracción a los requisitos del Art. 367 conduciría a la declaración de inadmisibilidad de la apelación y que esta inadmisibilidad podría ser declarada tanto por el tribunal de primera como de segunda instancia.

La exigencia de la escrituración en el escrito de apelación obliga a la agregación del recurso al "registro" o "expediente" judicial y deberá el escrito ser acompañado con las copias correspondientes a las otras partes o intervinientes, bajo apercibimiento legal (Arts. 31 del Código de Procesamiento Civil y 52 del Código Procesal Penal). En caso de que se utilicen medios electrónicos para configurar el registro, el recurso de apelación debe registrarse fiel e íntegramente y no en forma resumida (Art. 371).

\footnotetext{
${ }^{2}$ La Corte Suprema, mediante instructivo del 10.01.01 ha regulado el recurso de apelación, confirmando el criterio de que el recurso no puede interponerse verbalmente en las audiencias orales y que hasta el imputado privado de libertad debe necesariamente someterse al régimen de la apelación fundada, con peticiones concretas y mediante el escrito correspondiente.
} 


\section{h) Efectos del recurso de apelación y antecedentes que deben enviarse al tribunal de} alzada.

El artículo 368 establece que "la apelación se concederá en el sólo efecto devolutivo, a menos que la ley señalare expresamente lo contrario".

Como el Código Procesal Penal no define qué se entiende por "el sólo efecto devolutivo", habrá que recurrir a las nociones generales del Código de Procedimiento Civil, legislación supletoria del procedimiento penal (Art. 52).

El concepto de esta apelación limitada en sus efectos se encuentra regulado en el Art. 192 del Código de Procedimiento Civil y ello permite al tribunal inferior seguir conociendo de la causa hasta su terminación, incluso la ejecución de la sentencia definitiva.

Hay casos excepcionales en que la apelación se concede en ambos efectos por disposición expresa de la ley, como por ejemplo la apelación del Ministerio Público en contra de la resolución del juez de garantía que excluye algunas de las pruebas que ha ofrecido (Art. 277 inc. $2^{\circ}$ ).

Ahora bien, tanto en el caso de la apelación en el sólo efecto devolutivo que es la regla general, como en el de la apelación en ambos efectos, rige al efecto lo dispuesto en el artículo 371 que dispone que "concedido el recurso, el juez remitirá al tribunal de alzada copia fiel de la resolución y de todos los antecedentes que fueren pertinentes para un acabado pronunciamiento sobre el recurso". Esta materia está relacionada con la forma como se llevarán los registros judiciales y también con el tema de las compulsas a que se refiere el Art. 197 del Código de Procedimiento Civil.

Es pertinente reproducir algunos antecedentes de la historia del nuevo Código:

En la Cámara de Diputados se había aprobado una norma parecida al Art. 371 que resultó definitivamente aprobado. El texto de la Cámara, numerado como Art. 405 expresaba que "concedido el recurso, el juez remitirá al tribunal de alzada el texto de la resolución y copia de los registros de aquellas actuaciones o de la audiencia judicial en que se hubiere fundado".

En el segundo trámite, el Senado introdujo cambios formales en este precepto que pasó a ser el Art. 370, dejando constancia de lo siguiente:

En el Artículo 405, la Comisión reproduce el texto de la Cámara y agrega luego:

"Esta norma regula lo que hoy denominados las compulsas, que en la práctica son una pérdida de tiempo, porque la Corte normalmente pide que se le envíe el 
expediente original completo, porque considera insuficientes los documentos que se le remiten".

"En atención a estos antecedentes, la Comisión acordó que el tribunal a quo se deje copia de todos los antecedentes y envíe al tribunal de alzada la resolución y todos los antecedentes, originales o copias, que fueren pertinentes".

"En atención a la mayor importancia que cobran cada día los documentos electrónicos, la Comisión acordó dejar constancia que los documentos no sólo se refieren a aquellos que tienen soporte de papel, sino a cualquier medio tecnológico que permita su lectura o su percepción visual o auditiva. En cuanto a la regulación de la admisión y la forma en que deben registrarse los documentos tecnológicos, la Comisión estimó la conveniencia que fuera la misma Corte Suprema que lo hiciera a través de un auto acordado, a fin de uniformar los criterios de los tribunales".

De esta constancia no se deduce que esté eliminada la escrituración, sino que se admite también el uso de los documentos electrónicos y los medios tecnológicos más avanzados en los que estén registrados, tanto el recurso de apelación como todos los antecedentes necesarios.

En seguida, dicha constancia es muy conveniente para que la Corte Suprema haga uso de sus facultades económicas y dicte los autos acordados que sean necesarios para regular esta materia y también la relativa al recurso de nulidad y a los registros judiciales, teniendo presente que es posible que en los primeros tiempos de aplicación del nuevo sistema, sea necesario el envío de antecedentes escritos a la respectiva Corte que va a conocer de los recursos.

Por último, hay que referirse a la orden de no innovar que está prevista en el Art. 192 del Código de Procedimiento Civil en los casos de que la apelación se conceda en el sólo efecto devolutivo y que no se contempla expresamente en el nuevo Código Procesal Penal.

Estimamos que la orden de no innovar es aplicable también al nuevo procedimiento penal, no sólo por la aplicación supletoria de las normas del Código de Procedimiento Civil (Art. 52 del nuevo Código), sino que además, porque la orden de no innovar se inserta en la familia de las medidas cautelares que son de la esencia de las facultades conservadoras que debe tener todo tribunal. De allí que le sea aplicable también la normativa relativa a los efectos de la orden de no innovar y su tramitación en la Corte respectiva (Art. 192 inc. $2^{\circ}$ y $3^{\circ}$ ).

Si bien, el artículo 355 establece que por regla general, la interposición de un recurso no suspenderá la ejecución de una decisión, regla similar a la contenida en el artículo 192 inc. $1^{\circ}$ del Código de Procedimiento Civil, ello no sería impedimento para 
el ejercicio de la potestad cautelar de los Tribunales Superiores para decretar una orden de no innovar.

\section{i) Recurso de Hecho (Art. 369).}

Esta norma reproduce en forma similar lo dispuesto en el actual Art. 62 inc. $1^{\circ}$ del actual Código de Procedimiento Penal, es decir, ya no se distingue entre el verdadero y el falso recurso de hecho. Todos ellos tienen la misma regulación y tramitación.

Sin embargo, el nuevo Art. 369 precisa que el plazo para recurrir de hecho es de tres días, plazo legal que es fatal e improrrogable, salvo la situación muy excepcional prevista en el Art. 17. No hay aumentos en este plazo, ni siquiera en los casos en que el juez de garantía funcione en una comuna distinta a la que resida el tribunal de alzada, no aplicándose los criterios de aumento establecidos en el Art. 200 inc. $2^{\circ}$ del Código de Procedimiento Civil, porque la norma del Art. 369 es especial y no considera excepción alguna.

En cuanto a su tramitación, el recurso de hecho del nuevo proceso penal se presenta ante el tribunal de alzada, el que deberá solicitar los antecedentes indicados en el Art. 371 y luego debe fallar en cuenta, es decir, no se procede previa vista de la causa. Cuando una causa se falla en cuenta, no se admiten alegaciones orales de las partes o de sus abogados.

Existe un problema con el conocimiento del recurso en cuenta, porque en el nuevo sistema de vista de la causa se suprime la relación de los relatores como trámite de la misma (Art. 358 inc. $3^{\circ}$ ). Sin embargo, estimamos que se encuentran vigentes las normas establecidas en los Arts. 372 № 1 y $380^{\circ} 1$ del Código Orgánico de Tribunales que no fueron modificadas por la ley 19.665 que reformó el Código Orgánico de Tribunales para adecuarlo al nuevo proceso penal. Por consiguiente, la cuenta tendrán que hacerla los relatores y el secretario del antiguo sistema orgánico.

Aunque el Código no lo exprese, estimamos que el recurso de hecho debe presentarse por escrito al igual que el recurso de apelación, ya que es evidente que tendrá que detallar cuales son los antecedentes de la apelación que ha sido declarada improcedente o que ha sido concedida indebidamente.

Si la Corte acoge el recurso, debe retener los antecedentes o podrá recabarlos si no los hubiere pedido, para pronunciarse sobre la apelación (Art. 369 inc. $2^{\circ}$ ).

${ }^{3}$ La Corte Suprema en el instructivo ya mencionado del 10.01.01 ha estimado, por el contrario, de que la orden de no innovar no es procedente en atención a lo dispuesto en el Art. 355 del Código Procesal Penal. 


\section{j) Tramitación del recurso de apelación y nuevo sistema de la vista de la causa.}

Los artículos 356, 357 y 358 del nuevo Código se refieren a un nuevo sistema de vista de la causa que considera normas especiales que se apartan del régimen general de la vista de un recurso en los tribunales colegiados establecido en los artículos 163 a 166 del Código de Procedimiento Civil, 66 a 71 del Código Orgánico de Tribunales y 63, 63 bis y 63 bis a) del actual Código de Procedimiento Penal.

Sin embargo, las normas especiales del nuevo Código que se aplicarán a los nuevos procesos penales, no derogan ni hacen desaparecer las instituciones fundamentales que están reguladas en los actuales códigos y que ya se han mencionado. Aún más, no es posible aplicar el nuevo sistema y sus disposiciones especiales, sin tener que recurrir a los conceptos básicos que están definidos en la legislación procesal general del Código de Procedimiento Civil y del Código Orgánico de Tribunales.

Para entender el nuevo sistema de vista de la causa, deberemos acudir a algunas orientaciones y constancias que se contienen en el segundo informe de la Comisión de Legislación del Senado, que fue la instancia en que se promovieron los cambios que vamos a analizar, previa algunas referencias al proyecto aprobado por la Cámara de Diputados.

En la Cámara de Diputados, se aprobó el artículo 407 en que se establecía que una vez declarado admisible el recurso de apelación, el tribunal lo conocía y fallaba en cuenta, a menos que la resolución impugnada se hubiera dictado en audiencia verbal, en cuyo caso se resolvería previa vista de la causa. El proyecto agregaba que la vista de la causa sería pública y que habría una relación de los antecedentes y luego se concedería a las partes el uso de la palabra, sin perjuicio de que el tribunal podía formular preguntas a los presentes y permitir las aclaraciones respecto de las alegaciones de los otros intervinientes. Finalmente, se establecía que el Presidente del Tribunal dirigía el debate y podía eventualmente establecer excepciones a la publicidad de la audiencia.

La Comisión del Senado efectuó un amplio debate sobre el recurso de apelación y de su procedencia en el juicio oral. Respecto de su tramitación en la Corte de Apelaciones, la Comisión resolvió reestructurar la normativa de la Cámara, unificando en un solo procedimiento la tramitación del recurso de apelación y el de nulidad en las normas que en definitiva figuran en el Código como los artículos 356 a 361, es decir, estas normas están incluidas como disposiciones generales de los recursos.

Ahora bien, el artículo 395 del proyecto de la Cámara establecía que las apelaciones y las casaciones se verían sin esperar la comparecencia de las partes y que 
en consecuencia, no tendría aplicación lo dispuesto en el artículo 200 del Código de Procedimiento Civil.

Respecto de esta materia y en general del recurso de apelación, "si bien la Comisión estuvo en principio de acuerdo con este planteamiento, se generó un extenso intercambio de puntos de vista entre sus H.H. Srs. Integrantes acerca de la necesidad de dar reglas especiales para la tramitación de los recursos, por razones de coherencia, con los principios que inspiran al procedimiento penal desarrollado precedentemente en este Código. Estimó que no resultaría congruente, por ejemplo, la inmediación del tribunal y la contradictoriedad que inspira en el juicio oral con la aplicación de las actuales normas sobre vista de la causa que se aplican en los tribunales superiores. Le preocupó, asimismo, la incidencia que las reglas comunes de suspensión de la vista de la causa podrían tener en el despacho regular de las causas criminales".

En síntesis, el legislador trató de concretar en las nuevas normas sobre vista de los recursos, los principios de oralidad y de inmediación que caracterizan al juicio oral, distanciándose del ritual ordinario o corriente de los actuales recursos en su vista ante las Cortes.

Debe hacerse presente, sin embargo, que las apelaciones no están dirigidas en contra de resoluciones del juicio oral sino que de ciertas y determinadas resoluciones dictadas por los jueces de garantía ante los cuales no existe un juicio oral propiamente tal.

Como se ha observado, existen muchísimos vacíos en la nueva normativa que van a dar origen a distintas interpretaciones en las Cortes del país y que, seguramente, van a obligar a la Corte Suprema a la dictación de un auto acordado que regule más en detalle una materia bastante importante, ya que también influye en la tramitación del recurso de nulidad. ${ }^{4}$

\section{k) Comparecencia de los intervinientes en la segunda instancia.}

Este punto estaba regulado en el Art. 395 del proyecto de la Cámara que ya mencionamos, pero el Senado suprimió esta norma, dejando constancia que compartía el criterio de la Cámara y refundía el nuevo sistema en cinco artículos que regulaban la nueva vista de la causa.

Empero, el nuevo Código no se refiere específicamente a la comparecencia de los intervinientes como lo hacen el Código de Procedimiento Civil (Art. 200) y el Código de

${ }^{4}$ La Corte Suprema mediante acuerdo del 17.01.01 ha dado instrucciones a las Cortes de Apelaciones sobre el recurso de apelación, incluyendo las materias relativas a la admisibilidad del recurso y a la vista de la causa. 
Procedimiento Penal (Art, 63), Sin embargo, el Código de Procedimiento Civil es aplicable supletoriamente al nuevo procedimiento penal, en virtud de lo dispuesto en el Art. 52. La interrogante es si es necesaria la comparecencia de los intervinientes y si son aplicables las sanciones establecidas en el Art. 201 del Código de Procedimiento Civil. en particular la de deserción del recurso.

Sin perjuicio de que la Comisión dejó constancia de que compartía el criterio que eximía de la obligación de comparecencia en segunda instancia, que se establecía en el Art. 395 de la Cámara y que establece el actual Código de Procedimiento Penal en su Art. 63, la respuesta a esta interrogante está de algún modo resuelta en el nuevo Art. 358 inc. $2^{\circ}$ del nuevo Código Procesal Penal, que expresa textualmente:

“La falta de comparecencia de uno o más recurrentes a la audiencia dará lugar a que se declare el abandono del recurso respecto de los ausentes. La incomparecencia de uno o más de los recurridos permitirá proceder en su ausencia".

Al no encontrarse una mayor explicación de está normativa en la Comisión del Senado, nuestra lectura e interpretación es la siguiente:

a) No hay una obligación de comparecencia ante un tribunal de alzada de ninguno de los intervinientes en el plazo que se regula en el Art. 200 del Código de Procedimiento Civil y, por lo tanto, no hay sanción de deserción del recurso por no comparecencia del recurrente, porque la ley se preocupa únicamente de considerar la ausencia de los intervinientes el día de la audiencia y no en los primeros días de ingreso del recurso ante el tribunal superior.

b) La falta de comparecencia en el día de la audiencia de los recurrentes, no trae como consecuencia la deserción del recurso, sino que el abandono del mismo.

El Art. 358 no se preocupa de establecer en qué consiste esta novedosa sanción que no tiene precedentes en la legislación procesal chilena sobre recursos procesales.

¿Constituye el abandono del recurso una terminación anticipada o anormal del mismo? ¿Puede el tribunal de alzada, no obstante este abandono, proceder al conocimiento del recurso?

Al parecer, la interpretación más lógica es la de estimar que el recurso de apelación termina allí mismo en la audiencia al verificarse por la Corte que el recurrente no ha comparecido y que este abandono debe declararse de oficio, sin que sea menester petición de parte. Es decir, si el recurrente no ha comparecido el día de la audiencia, ésta no puede continuar y tampoco la Corte puede conocer del recurso. Esta interpretación armoniza además con los principios generales que inspiran el nuevo sistema de recursos que no aceptan la actuación oficiosa o de control que puedan 
ejercer los Tribunales Superiores de Justicia, lo que llevó además a suprimir enteramente el trámite de la consulta (ver referencias a explicaciones del Profesor Carocca, pág. 3) y también con la consideración de que la apelación en el nuevo sistema, es excepcional.

Por lo tanto, en el caso de que haya sido el Ministerio Público la parte recurrente, es absolutamente necesario que el Fiscal que lo represente comparezca y participe el día de la audiencia y efectúe las alegaciones de rigor, de lo contrario el recurso se declarará abandonado.

En el caso de que existan varios recurrentes y sólo uno de ellos no haya comparecido a la audiencia, el abandono del recurso sólo afectará al recurrente inasistente.

El tema deberá volver a analizarse con mayor profundidad tratándose del recurso de nulidad, puesto que en este recurso, se admite restringidamente una actuación de oficio del tribunal ad quem (Arts. 375 y 379 inc. $2^{2}$ ).

c) Respecto de los intervinientes recurridos, es decir, de aquellos que no han recurrido, el Art. 358 inc. $2^{\circ}$ establece que se "permitirá proceder en su ausencia", en caso de falta de comparecencia a la audiencia.

Esta fórmula legal tampoco es muy clara y precisa, ya que si bien se estaría indicando que la audiencia puede efectuarse en su ausencia, la expresión "permitirá", da a entender que estamos en presencia de una facultad y no de una obligación del tribunal y así algunos sostendrán que no obstante esta norma, la Corte puede considerar que no se puede proceder en su ausencia.

La interpretación más sólida consiste en que no se puede suspender la audiencia por falta de comparecencia de uno o más de los recurridos, porque la apelación es excepcional y porque no se puede dilatar la marcha del nuevo proceso penal.

Esta interpretación tiene importancia respecto de los fiscales, ya que se ha escuchado en más de alguna ocasión una opinión en el sentido de que su comparecencia a la audiencia es obligatoria para exponer los puntos de vista de la Fiscalía, como recurrente o recurrido.

Si el Ministerio Público es parte recurrida, si bien no está obligado a concurrir a la audiencia, ello puede ser muy conveniente si resulta indispensable para defender la resolución recurrida.

d) La referencia del Art. 358 a los recurrentes y a los recurridos, no importa una derogación de las reglas generales del Código Orgánico de Tribunales y de la Ley de comparecencia en juicio, № 18.120 que no fueron modificadas por la Ley 19.665. El 
Art. 527 del Código Orgánico de Tribunales circunscribe las alegaciones orales ante cualquier tribunal de la República a los abogados habilitados para el ejercicio de la profesión y, en determinados casos, a los postulantes que están realizando su práctica para obtener el título de abogado en las Corporaciones de Asistencia Judicial creadas por la ley 17.995, siempre que tales defensas se realicen ante las Cortes de Apelaciones y Marciales a favor de las personas patrocinadas por estas entidades. Por su parte, la ley 18.120 establece la obligación de designar abogado patrocinante y conferir mandato judicial a persona habilitada, por regla muy general. Finalmente, el Art. 398 establece las reglas respectivas que rigen la comparecencia ante la Corte Suprema o ante las Cortes de Apelaciones.

De modo que no es necesario que se presenten personalmente a la audiencia el recurrente o el recurrido, porque rigen las reglas generales sobre el mandato judicial y la comparecencia en juicio, tomando esta expresión en sentido amplio.

Estimamos que, salvo mejor parecer de la jurisprudencia, ninguna Corte podría exigir como requisito obligatorio la comparecencia personal de los intervinientes, porque no se encuentran derogadas las reglas generales sobre la representación por intermedio de abogados, sin perjuicio de la presencia facultativa de las partes en el desarrollo de la audiencia.

Además, la tesis contraria obligaría a la presencia del imputado privado de libertad en la audiencia de la Corte, con el consiguiente traslado por Gendarmería de Chile y los problemas de seguridad que ello trae, y aún más, sería excesivo sancionar a la persona privada de libertad que ha recurrido con el abandono del recurso, si no se presenta personalmente ante el Tribunal Superior para la vista de un recurso de apelación o de nulidad. Hay que tener presente, además, que la jurisprudencia uniforme de los tribunales ha considerado, hasta ahora, que el procesado privado de libertad, siempre está representado por el abogado y procurador de turno y que no rigen a su respecto las consecuencias que afectan a los litigantes ausentes.

\section{I) Tramitación del recurso cuando ingresa a la Corte y antes del día de la audiencia.}

El nuevo Código no contiene normas al respecto y el problema consiste en saber si son aplicables las reglas generales del Código de Procedimiento Civil, vale decir sus Arts. $199,200,213$ y 214 .

Nuestra respuesta es que, en general, son aplicables supletoriamente las normas comunes del procedimiento civil, salvo cuando exista una oposición a lo estatuido en el Código Procesal Penal (Art. 52). 
Por lo anterior, será necesario interpretar y suplir la ausencia de normativa del nuevo Código Procesal Penal, en la forma que pasa a exponerse:

a) Nos parece claramente que sigue vigente un sistema de ingreso de los recursos al Tribunal Superior o ad quem, que estará a cargo de la secretaría del tribunal (Art. 200 inc. $1^{\circ}$ del Código de Procedimiento Civil y 380 № 4 del Código Orgánico de Tribunales).

Sin embargo, este sistema de ingreso de los nuevos recursos tendrá que hacerse separadamente de los recursos del sistema antiguo y su reglamentación dependerá de los autos acordados de las Cortes de Apelaciones respectiva y en su caso de la Corte Suprema.

Para evitar las confusiones, podría ser conveniente el uso de roles, papelería y tecnología distintas para los nuevos recursos, máxime que en la vista de éstos no intervendrá un relator y una relación previa de los antecedentes.

b) La primera providencia no podrá consistir en ordenar traer los autos en relación puesto que el Art. 358 inc. $3^{\circ}$ del nuevo Código establece que las audiencias se iniciarán con el anuncio, "tras el cual, sin mediar relación, se otorgará la palabra...".

Tampoco la primera providencia puede consistir en ordenar que se dé cuenta del recurso en la sala respectiva, porque los recursos de apelación y de nulidad no se ven en cuenta, sino previa vista de la causa. Sólo el recurso de hecho se ve en cuenta y allí es correcto ordenar que se dé cuenta del recurso.

¿Cuál podría ser la primera providencia? Se nos ocurre que al tribunal de alzada sólo le corresponde fijar la audiencia pública en la cual se procederá a la vista de la causa, lo que significa que el Presidente de la Corte debe incluir la causa en una tabla semanal, salvo la situación de las causas agregadas que se ven extraordinariamente. Por ello, la primera providencia podría consistir en una resolución que disponga pasar los antecedentes al Presidente de la Corte para los fines previstos en los Arts. 69 y 70 del Código Orgánico de Tribunales, pero ésta es un decreto o mero proveído de mera sustanciación.

Ahora bien, la existencia de una tabla para estos recursos especiales del nuevo sistema no puede ponerse en duda por las distintas referencias contenidas en los Arts. 356 y 357 que inequívocamente suponen que las causas figuran o en la tabla semanal o agregadas extraordinariamente.

Asi, por ejemplo, el Art. 357 inc. $2^{\circ}$ dispone que "al confeccionar la tabla o disponer la agregación extraordinaria de recursos o determinar la continuación para el 
día siguiente de un pleito, la Corte adoptará las medidas necesarias para que la sala que correspondiere no viere alterada su labor".

Más adelante, el inciso $4^{\circ}$ del Art. 357 permite suspender la vista de la causa en determinadas circunstancias, pero exige que los solicitantes presenten un escrito hasta las doce horas del día hábil anterior a la audiencia correspondiente, a menos que la agregación de la causa se hubiere efectuado con menos de setenta y dos horas antes de la vista..."

Por último, todo el sistema de suspensión de la vista de la causa supone que los recursos están fijados o en una tabla o agregados extraordinariamente y que, ninguno puede verse sin figurar en tabla o ser agregado extraordinariamente, mediante los sistemas de distribución previstos en los Arts. 69 y 70 del Código Orgánico de Tribunales.

Esta tabla de los recursos del nuevo sistema debería, por razones de conveniencia, ser una especial para evitar su confusión con las tablas civiles y penales del antiguo sistema en que existe una relación previa a cargo de un relator. Esta tabla especial no contendría el nombre de un relator y en cambio, tendría que establecer un orden correlativo para posibilitar el anuncio de la causa el día en que se vea.

Hay que tener presente que durante un lapso más o menos largo, coexistirán recursos del sistema antiguo y también del sistema nuevo, siendo imposible que en una misma tabla y a cargo de un mismo relator, figuren ambos tipos de recursos de características tan diferentes.

c) No se encuentra regulado en el nuevo Código, en lo que concierne al recurso de apelación, el control de la admisibilidad del recurso cuando ingresa a la Corte. En cambio, en el recurso de nulidad está considerado expresamente el control de la admisibilidad por el tribunal a quo (Art. 380) y por el tribunal ad quem (Art. 383).

¿Constituye esta omisión una falta de atribuciones de la Corte para declarar inadmisible un recurso de apelación?

A nuestro juicio, la respuesta es que todo tribunal de segunda instancia siempre tiene la facultad de declarar la inadmisibilidad de un recurso, ya sea porque ha sido interpuesto fuera de plazo o $\sin$ las formalidades y requisitos legales. Si el tribunal de alzada puede conocer del recurso, está implícito en sus facultades, que también puede rechazarlo por inadmisible.

Si no se considerara por razones de interpretación literal, el control de admisibilidad en segunda instancia, tampoco podría aplicarse al tribunal de primera instancia, porque ningún texto legal lo autoriza para declarar inadmisible un recurso de 
apelación. Sin embargo, esta facultad está implícita en la regulación del recurso de hecho que justamente procede cuando el tribunal ha denegado indebidamente la concesión del recurso de apelación, de modo que, ello está indicando que existe un control de admisibilidad en la primera instancia. En conclusión, sería contrario a todo el sistema permitir un control de admisibilidad sólo en la primera instancia y dejar a la Corte inhibida de pronunciarse sobre la admisibilidad y, a mayor abundamiento, rige al respecto como norma supletoria lo dispuesto en el Art. 213 del Código de Procedimiento Civil.

Se puede encontrar, además, en la historia de la ley, un antecedente que confirma la tesis de que subsiste un doble control de admisibilidad, tanto por el tribunal de primera como el de segunda instancia. En la Comisión del Senado, al comentarse el artículo 399 aprobado por la Cámara, se consideró que contemplaba un doble control de admisibilidad, tanto en primera como en segunda instancia, pero la Comisión consideró que era innecesario decirlo expresamente, porque ante "una negativa injustificada del tribunal a quo, existe siempre el recurso de hecho". Es decir, no es que no exista un control de admisibilidad amplio, sino que la ley otorga el remedio para impugnar una inadmisibilidad injustificada, cual es el recurso de hecho.

Sin embargo, como no existe un trámite previo a la audiencia pública en que se verán los recursos de apelación, la conclusión forzosa es que el control de admisibilidad se hace en la misma audiencia pública y no puede hacerse antes por la Corte.

\section{m) Emplazamiento en la segunda instancia.}

No está regulado el tema del emplazamiento de los intervinientes para participar en la segunda instancia. Hoy en día, ningún recurso ordinario puede verse sin un emplazamiento previo en la segunda instancia que consiste en la notificación de la concesión del recurso en primera instancia y el transcurso del término de emplazamiento para comparecer a la segunda instancia, considerando como tal, el plazo de comparecencia que por regla general es de cinco días. Esto se altera en el caso de las agregaciones extraordinarias en que el emplazamiento es mínimo. Además, el artículo 221 dispone que la primera resolución que se dicta por un tribunal de alzada debe ser personal, sin perjuicio de lo dispuesto en los Arts. 201 y 202, todos ellos del Código de Procedimiento Civil.

Para suplir este vacío habrían dos interpretaciones. Una posible, es sostener que en el nuevo sistema no hay emplazamiento en la segunda instancia y, por lo tanto, los recursos pueden verse en cualquier momento después de su ingreso. Una segunda, que nos parece más razonable, es la de considerar que debe existir un mínimo emplazamiento en segunda instancia, de modo de posibilitar a los intervinientes, en especial al recurrente, el poder intervenir en la audiencia respectiva, máxime que si no 
lo hace se produce el abandono del recurso. El emplazamiento sería una condición básica del debido proceso en lo que se refiere al derecho de ser escuchado en todas las etapas del proceso.

Con el objeto de tratar de llegar a una solución en un problema delicado y particularmente oscuro, nos referiremos a ciertos antecedentes de la tramitación del proyecto en el Senado, luego de redactarse los primeros borradores relativos a las normas generales sobre los recursos.

En un borrador redactado por la Secretaría de la Comisión, al 11 de mayo del 2000, aparecía en los artículos 395 y 407 sobre reglas generales de tramitación de los recursos, un inciso $1^{\circ}$ que expresaba lo siguiente:

"Por regla general los recursos serán conocidos por el tribunal que debe resolverlos por medio de una audiencia pública a la que serán citados el o los recurrentes y el o los recurridos".

A continuación, venía un inciso $2^{\circ}$ que es idéntico al que aparece como el actual Art. 358 inc. $2^{\circ}$ del Código, referido a los efectos de la inasistencia de los recurrentes 0 de los recurridos a la audiencia pública.

Podemos recordar que varios de los asistentes a la Comisión manifestaron que esta citación de los recurrentes y recurridos era poco precisa y difícil de cumplir durante la tramitación de los recursos en la Corte. ¿Era esta una notificación personal? ¿También se exigía en las causas que debían agregarse extraordinariamente?

También podemos recordar que cuando los miembros de la Comisión de Legislación del Senado y el Fiscal Nacional concurrieron a la Corte Suprema para informar del nuevo sistema de recursos, entre otras materias, varios Srs. Ministros impugnaron este doble sistema de la vista de la causa que se pretendía regular, por razones de orden práctico y organizativas.

A consecuencia de estas observaciones, la Comisión sustituyó el inciso $1^{\circ}$ que obligaba a citar a las partes por uno nuevo en que simplemente expresó:

"La vista de la causa se efectuará en una audiencia pública" (Art. 358 inc. $1^{\circ}$ del nuevo Código).

Por consiguiente, basándonos en estas consideraciones e historia de la ley, concluimos que no existe ningún trámite previo antes de la audiencia pública, salvo la inclusión del recurso en una tabla o la agregación extraordinaria en los casos excepcionales en que procede (Arts. 69 y 70 del Código Orgánico de Tribunales), y que no es necesario citar o notificar a los intervinientes de ninguna resolución judicial previa que pueda estimarse como una especie de emplazamiento. 
El emplazamiento de la segunda instancia estaría constituido únicamente con la notificación de la resolución que concede el recurso y la figuración en tabla o la agregación extraordinaria dispuesta por el Presidente de la Corte, aplicando los sistemas de distribución de los Arts. 69 y 70 del Código Orgánico de Tribunales.

\section{n) Nuevo sistema de la vista de la causa.}

Los artículos 356 y 357 del nuevo Código, establecen reglas especiales para la suspensión de la vista de la causa que se aplican a todos los recursos, incluyendo los de apelación y de nulidad.

La primera conclusión es que en todo lo no dispuesto en estas reglas especiales, rigen las reglas generales contenidas en los Arts. 163, 164, 165 y 166 del Código de Procedimiento Civil.

La otra conclusión es, que no obstante las peculiaridades del sistema mediante el cual la Corte conoce de los recursos del nuevo proceso penal, lo que llevó a la Comisión del Senado a dejar establecido que trataba de "extender el sistema de desarrollo de la audiencia del juicio oral que establece el nuevo Código, que respeta cierta estructura sin ser ritualista, al desarrollo de la vista de la causa en los tribunales superiores" y más adelante agrega la Comisión "nos ha parecido conveniente, en esta materia, dar reglas generales que mantengan principios como la inmediación del tribunal y la contradictoriedad que inspiran al juicio oral", no se suprimió el sistema tradicional de la vista de la causa y sólo se impusieron algunas reglas especiales cuyo alcance veremos más adelante.

La Comisión hubiera querido un sistema distinto que no fuera ritualista y que reprodujera en pequeña escala lo que es un juicio oral, pero este propósito no pudo concretarlo por la premura del tiempo y la falta de un mayor rigorismo procesal que exige una coordinación con toda la sistemática procesal vigente.

a) Reglas especiales en materia de suspensiones de la vista de la causa.

a.1. Mediante una primera regla (Art. 357 inc. $1^{\circ}$ ), "la vista de la causa no podrá suspenderse por las causales previstas en los numerales 1, 5, 6 y 7 del artículo 165 del Código de Procedimiento Civil".

\footnotetext{
${ }^{5}$ En el instructivo mencionado del 17.01.01, la Corte Suprema establece que los intervinientes tienen un plazo de cinco dias para comparecer ante el tribunal de alzada y que el recurso no puede verse antes de este plazo, salvo que se trate de una agregación extraordinaria relacionada con la libertad de un imputado. La Corte no regula cual sería la sanción por la falta de comparecencia, como, por ejemplo, la deserción del recurso. En nuestro concepto. no hay deserción del recurso en materịa penal, no obstante que el nuevo Código no haya regulado esta materia.
} 
Por consiguiente, rigen las causales №s 2, 3 y 4 del Art. 165 que se refieren a la "falta de miembros del tribunal en número suficiente para pronunciar sentencia", o a la "muerte del abogado patrocinante, del procurador o del litigante que gestione por si en el pleito" - "la muerte del cónyuge o de alguno de los descendientes o ascendientes del abogado defensor, ocurrida dentro de los ocho días anteriores al designado para la vista".

Esta aplicación expresa de las causales de suspensión ya mencionadas, confirma la tesis de que la presencia del abogado patrocinante de los intervinientes es estrictamente indispensable el día de la audiencia pública, sin que pueda ser sustituido por la presencia personal de los intervinientes, sea recurrentes o recurridos, aun cuando es distinta la consecuencia de la ausencia del abogado defensor del recurrente y la de los abogados de los recurridos.

a.2. Si bien rigen las causales de suspensión de los №s 3 y 4 del Art. 165 del C.P.C., si se trata de una causa en que hubiere personas privadas de libertad "sólo se suspenderá la vista de la causa por muerte del abogado del recurrente, del cónyuge o de alguno de sus ascendientes o descendientes, ocurrida dentro de los ocho días anteriores al designado para la vista del recurso" (Art. 357 inc. $3^{\circ}$ ).

Esta regla especial es casi idéntica a la № 4 del Art. 165 del Código de Procedimiento Civil y se diferencia sólo en cuanto a que la muerte del abogado del recurrente o de sus ascendientes o descendientes, es la que permite suspender la vista de la causa.

a.3. En cuanto a la suspensión solicitada por las partes de la vista de la causa, el Art. 357 inc. $4^{\circ}$ establece una regla especial que se aparta del sistema contemplado en el Art. 165 № 5 del Código de Procedimiento Civil.

En efecto, el Art. 357 inc. $4^{\circ}$ dispone que: "En los demás casos la vista sólo podrá suspenderse si lo solicitare el recurrente o todos los intervinientes facultados para concurrir a ella, de común acuerdo. Este derecho podrá ejercerse una sola vez por el recurrente o por todos los intervinientes, por medio de un escrito que deberá presentarse hasta las doce horas del día hábil anterior a la audiencia correspondiente, a menos que la agregación de la causa se hubiere efectuado con menos de setenta y dos horas antes de la vista caso en el cual, la suspensión podrá solicitarse hasta antes de que comenzare la audiencia".

Es decir, sólo el recurrente puede suspender la vista de la causa y no el recurrido, sin perjuicio de que pueden solicitar la suspensión todos los intervinientes facultados para concurrir a la vista, de común acuerdo. 
¿Y qué se entiende por intervinientes facultados para concurrir a la vista? No hay una indicación en la historia de la ley que nos ayude a resolver esta duda. Por ahora, el único alcance de esta expresión consistiría en que sólo se admita a los intervinientes que han participado en el proceso, al momento de dictarse la resolución objeto del recurso, a menos que decida participar por primera vez en la Corte y este tribunal admita su intervención.

La otra duda que se va a plantear, es si este escrito de suspensión de la vista, tiene que pagar el impuesto especial a que se refiere el Art. 165 № 5 inc. $3^{\circ}$.

Puede que algunos sostengan que en el nuevo sistema no hay impuestos de este tipo, pero una respuesta más segura consiste en sostener que los impuestos se seguirán exigiendo toda vez que lo que no rige es la causal de suspensión de la vista del № 5 del Art. 165, pero que, en lo que respecta a los otros requisitos de la suspensión, rige la regla general y entre estos requisitos se encuentra el pago del impuesto especial del inciso $3^{\circ}$ del № 5 del Art. 165. Este punto tendrá que ser resuelto internamente por los Tribunales Superiores de Justicia.

a.4. No puede suspenderse la vista de un recurso penal por falta de jueces que pudieren integrar la sala (Art. 356).

Para evitar toda posible suspensión, se dispone "que se interrumpirá la vista de recursos civiles para que se integren a la sala jueces no inhabilitados", fórmula legal que tendrá que ser implementada por la Corte, porque es muy difícil que una causa civil cuyos recursos se están viendo, pueda ser interrumpida en razón de que faltan jueces para integrar la sala que debe conocer los recursos penales.

Si un recurso de una causa civil se interrumpe, ¿cómo.continúa después?, ¿o es que queda sin efecto la vista del recurso civil por falta de jueces? ¿se permite en estos casos que integren posteriormente nuevos jueces al conocimiento de la causa civil?

A primera vista, la causa civil interrumpida tendrá que continuar el día que determine la Corte con los mismos ministros y el relator tendrá que certificar cual es el estado de la causa interrumpida, para posibilitar su continuación. No obstante, tendrá que ser la propia Corte la que reglamente este vacío en el procedimiento de los recursos del nuevo sistema,

Finalmente, si ni aun con la interrupción de la vista de recursos civiles, puede completarse el número de jueces que deben intervenir en la causa penal, tendría que suspenderse la audiencia respectiva, porque el Art. 356 dispone que "la audiencia sólo se suspenderá si no se alcanzare, con los jueces que conformaren ese día el tribunal, el mínimo de miembros no inhabilitados que debieren intervenir en ella". 
a.5. En cuanto a la recusación de los abogados integrantes o de los otros integrantes de las Cortes, en que el nuevo sistema no contiene regla alguna, habrá que aplicar las normas generales pertinentes, en especial los Arts. 198 y siguientes del Código Orgánico de Tribunales y 166 del Código de Procedimiento Covil, incluyendo el pago del impuesto especial de recusación.

\section{b) Audiencia pública en que se procede a la vista de los recursos.}

Tradicionalmente, se ha definido la vista de la causa como un trámite complejo compuesto de varios actos sucesivos y esenciales la mayoría de ellos, que son los siguientes:

\section{b.1. Dictación del decreto en relación y su notificación a las partes.}

Es obvio que este trámite no existe en el nuevo sistema, porque en la audiencia pública, luego del anuncio, se ofrece la palabra a los intervinientes "sin mediar relación"; lo que significa que no existe el trámite de la relación a cargo del funcionario auxiliar denominado relator.

b.2. Figuración de la causa en tabla o agregación extraordinaria del recurso, conforme lo establece el artículo 69 del Código Orgánico de Tribunales y 163 inc. $1^{\circ}$ del Código de Procedimiento Civil.

Reiteramos lo anteriormente expuesto en el sentido de que el nuevo sistema no sólo no prescinde de estos trámites, sino que expresamente se refiere a ellos en el Art. 357 inc. $2^{\circledR}$ del Código Procesal Penal.

\section{b.3. El anuncio de la causa el día en que debe verse.}

El anuncio está indicado como trámite esencial en el artículo 163 inc. $2^{2}$ del Código de Procedimiento Civil y sigue vigente en el nuevo sistema procesal penal, porque no hay regla especial en contrario y porque la referencia al anuncio, está expresamente dicha en el Art. 358 inc. $3^{\circ}$ que dispone que "la audiencia se iniciará con el anuncio".

Por consiguiente, continuarán aplicándose las reglas tradicionales sobre el anuncio de las causas que se ven, como forma de resguardar el debido emplazamiento de las partes que concurren a la audiencia.

b.4. La inscripción de los abogados cuando deseen anunciarse para alegar en la vista de la causa (Art. 223 del Código de Procedimiento Civil, complementado por el Auto Acordado de la Corte Suprema de 2 de septiembre de 1994). 
En esta materia no hay innovaciones en el nuevo Código Procesal Penal y estimamos que las Cortes continuarán rigiéndose por estas mismas reglas, con los problemas de interpretación que todos conocemos, salvo que los abogados no podrán anunciarse ante el relato $\zeta$ de la causa, toda vez que en el nuevo sistema no hay relator y tampoco relación. La Corte tendrá que disponer un sistema operativo para que los abogados puedan anunciar con la anticipación debida, su intención de alegar el recurso y participar en la audiencia pública.

En un reciente Auto Acordado del 01.12.00, la Corte Suprema ha instruido a las Cortes para que los anuncios de los alegatos puedan ser efectuados por escrito con veinticuatro horas de anticipación al inicio de la respectiva audiencia o el mismo día, antes del inicio de la audiencia, a través del abogado o del procurador del número a quien se le haya conferido poder.

b.5. Conocimiento de los antecedentes del recurso por los jueces del tribunal colegiado.

No habiendo relación, los ministros deberán interiorizarse por si mismos acerca de los antecedentes del recurso.

Según algunas opiniones, los jueces no podrían ver los antecedentes con anterioridad a la audiencia pública, pero esto no está expresado en la ley y bien pueden los miembros del tribunal examinar los antecedentes antes de escuchar al recurrente y recurridos. Esta también es una materia que deberá ser regulada por la Corte, mediante instrucciones generales o Autos Acordados.

\section{b.6. Desarrollo de la audiencia pública (Art. 358).}

En esta materia hay reglas especiales que se apartan del sistema de vista de la causa establecido en el Art. 223 del Código de Procedimiento Civil.

Sea que la Corte esté impuesta o no de los antecedentes del recurso, la audiencia pública se inicia con la exposición del o los recurrentes para explicar los fundamentos del recurso y las peticiones concretas que formularen. Entendemos que los fundamentos pueden ser de hecho y de derecho y que continúan vigentes los Arts. 225 y 226 del Código de Procedimiento Civil que sólo permiten que alegue un abogado por

\footnotetext{
${ }^{6}$ En Auto acordado del 01.12.00, dictado antes de la entrada en vigencia de la reforma procesal penal en la IV y IX regiones, la Corte Suprema ha instruido a las Cortes para que los anuncios de los alegatos pudieran efectuarse no sólo antes de la audiencia el mismo dia, sino que también por escrito con veinticuatro horas de anticipación al inicio de la respectiva audiencia, a través del abogado o procurador del número que tenga poder. En el instructivo del 17.01.01, ya mencionado, impartido después de la entrada en vigencia de la reforma procesal penal en las mismas regiones, la Corte Suprema ordena que los abogados deben inscribirse previamente ante el relator para su alegato, instrucción que ha merecido dudas a la Corte de Apelaciones de Temuco por estimar que en la vista de la causa en el nuevo sistema no hay intervención de relator y tampoco habrian alegatos propiamente tales.
} 
cada parte y que prohíbe al abogado leer en la audiencia su defensa y presentar defensas escritas.

Luego que termine la exposición del recurrente se permite intervenir a los recurridos y aunque la ley no lo dice, es dable suponer que lo hacen para controvertir los fundamentos del recurso.

Una vez que termina la intervención del recurrido, a través de su abogado, el tribunal vuelve a ofrecer la palabra a todas las partes "con el fin que formulen aclaraciones respecto de los hechos o de los argumentos vertidos en el debate".

En nuestra estimación, estas aclaraciones son amplias y no están circunscritas a la rectificación de los hechos como sucede actualmente. Es decir, existiría un derecho amplio a la réplica.

La ley no especifica el orden de las réplicas, por lo que es lógico suponer que será el mismo de sus intervenciones primitivas, esto es, primero el recurrente y luego el recurrido. Tampoco se regula el orden de las exposiciones de los recurrentes y recurridos, en caso de haber dos o más, por lo que no habrá otra solución que aplicar por analogía lo dispuesto en el artículo 223 inc. $2^{\circ}$ del Código de Procedimiento Civil.

En cuanto a la duración de los alegatos o exposiciones, la ley no establece un límite y va a tener que ser reglamentado por auto acordado de la propia Corte y bien puede que se mantenga el límite máximo de media hora por cada alegato (Art. 223 inc. $4^{\circ}$ ) o bien, puede ser que la Corte lo limite aun más por tratarse de recursos del nuevo sistema en que se supone una mayor celeridad y abreviación.

Los miembros del tribunal, en cualquier momento del debate pueden "formular preguntas a los representantes de las partes o pedirles que profundicen su argumentación o la refieran a algún aspecto específico de la cuestión debatida".

Por consiguiente, las preguntas del tribunal deben ser contestadas por los representantes de las partes y no por las partes personalmente. Esto confirma que en la vista de los recursos del nuevo sistema, actúan los representantes de los intervinientes que son los abogados y no las partes mismas, es decir, continúa vigente el sistema de representación legal en juicio de la ley 18.120 y las reglas pertinentes del Código Orgánico de Tribunales.

En cuanto a las reglas sobre los acuerdos, hay una regla especial que se consigna en el inciso final del Art. 358 y que establece que "concluido el debate, el tribunal pronunciará sentencia de inmediato o, si no fuere posible, en una día y hora que dará a conocer a los intervinientes en la misma audiencia". 
Esta regla especial es un intento de traducir a la práctica, el principio de la inmediación y concentración que prima en el juicio oral.

Sin embargo, el tribunal puede dilatar la dictación de la sentencia para una audiencia próxima y su realización no tiene un límite máximo en el tiempo. Lo único que se exige, es que los intervinientes sean convocados al término de la vista del recurso para una nueva audiencia para conocer del fallo.

Tampoco el nuevo Código regula lo que sucede en el caso de que un recurso quede en acuerdo a la espera del fallo definitivo. En atención a que no existe un relator que esté presente en la audiencia o haya relatado el recurso, ningún relator podría certificar cuáles son los ministros que han entrado al acuerdo y la fecha del acuerdo. Es posible que para suplir este vacío, la Corte le encomiende al secretario actuar como ministro de fe y estampar bajo su responsabilidad un certificado del tenor ya señalado.

En el recurso de nulidad, hay una regla especial distinta en el artículo 384 en que se permite dictar él fallo en un plazo de hastá veinte días, razón por la cual nos referiremos a esta regla en el análisis del recurso de nulidad, sin perjuicio de que igualmente se le aplican las reglas sobre la audiencia pública contempladas en el Art. 358 del Código Procesal Penal.

En lo que se refiere al resto de las reglas sobre los acuerdos, tendrán que regir las reglas generales del Código Orgánico de Tribunales, es decir, los Arts. 72 y siguientes.

No está resuelto el tema relativo a las medidas para mejor resolver en el nuevo Código Procesal Penal, en la vista de las causas. Hay opiniones en el sentido de que ellas no estarían permitidas en el nuevo sistema por su carácter acusatorio y no inquisitivo. El punto es discutible si se considera que pueden faltar antecedentes que la Corte estime indispensables para mejor acierto del fallo, sin perjuicio de la posible aplicación supletoria del Código de Procedimiento Civil (Art. 52 del Código Procesal Penal), por lo que también se requiere de una reglamentación legislativa o de los tribunales superiores.

Finalmente, la Corte tendrá que dictar una resolución de segunda instancia que confirme, modifique o revoque la sentencia apelada y por ello deberá cumplir con los requisitos formales a que se refieren los Arts. 170 y 171 del Código de Procedimiento Civil. 


\section{b.7. La prueba en el recurso de apelación.}

No está permitida la prueba en el recurso de apelación, puesto que el artículo 359 del Código Procesal Penal sólo establece su procedencia en el recurso de nulidad, sin que exista igual norma respecto del recurso de apelación.

En consecuencia, el tribunal de alzada deberá resolver únicamente en mérito a los antecedentes del recurso que ha tenido que enviarle el tribunal de primera instancia, en los términos previstos en el Art. 371.

\section{b.8. La decisión del recurso de apelación (Art. 360).}

Esta norma especial contiene varios principios. En primer término se acaba con el criterio de la "reformatio in peius" del actual Art. 528 del Código de Procedimiento Penal, es decir, la Corte sólo puede pronunciarse sobre las solicitudes de los recurrentes y no puede reformar la resolución apelada "en perjuicio del recurrente" (Art. 360 inc. $1^{\circ}$ y $3^{\circ}$ del nuevo Código).

La Corte no puede extender, de oficio, su pronunciamiento más allá de lo pedido por el recurrente $y$ al respecto reiteramos el criterio que inspira el nuevo sistema que procura evitar que la Corte ejerza un papel de control sobre la legalidad de las decisiones del tribunal inferior y por ello es que suprimió el trámite de la consulta. Hay excepciones en el recurso de nulidad contempladas en el Art. 379 inc, $2^{\circ}$ del nuevo Código, que deben analizarse al tratar el recurso de nulidad.

Por último, se establece una regla especial en el sentido de que la decisión favorable a uno de varios imputados, aprovecha a los demás, "a menos que los fundamentos fueren exclusivamente personales del recurrente, debiendo el tribunal declararlo así expresamente" (Art. 360 inc. $2^{\circ}$ del nuevo Código). 